\title{
William Byrd's Fall From Grace and his First Solo Publication of 1588: A Shostakovian "Response to Just Criticism"?
}

\section{JEREMY L. SMITH}

Was Byrd the Shostakovich of his time? Surely the aptness of this analogy has occurred to others. Few matters in musicology were more widely discussed not too long ago than the premise that Dmitry Shostakovich had a close if, as some fervently argued, essentially dissident relationship with Josef Stalin, the de facto leader of the Soviet Union for nearly a quarter century (c.1929-53).1 Evidence of a similar political relationship between Byrd and England's long-reigning ruler Elizabeth I (r.1558-1603) is mainly confined to discussions in the traditional musicological literature. But readers of the widely distributed New York Review of Books have lately been exposed to claims that Byrd's great contemporary William Shakespeare had strong ties to the Catholic cause during a time when England was under statutory Protestant rule. ${ }^{2}$ Thanks to a seminal essay Joseph Kerman had placed in those same pages some time ago-that has now been complemented and furthered by Kerman himself, Philip Brett, David Mateer, Craig Monson, and others-the NYRB audience at least has been alerted to the circumstance that if there were indeed a dissident platform on which Shakespeare stood, Byrd stood alongside him, and on a much surer footing. ${ }^{3}$

Shostakovich won the remunerative Stalin Prize twice (1947 and 1953). ${ }^{4}$ He wrote sincerely patriotic music during wartime, praised Stalin's leadership enthusiastically, and offered a musical tribute to the dictator's grandiose but ill-conceived project to halt the desiccating winds from eastern

1 See Music Under Soviet Rule, The Shostakovich Debate, created by the late Ian McDonald, maintained by Southern University at Edwardsville, http://www.siue.edu/ aho/musov/deb/deb.html (accessed 23 December 2006). It includes a lengthy, defensive treatment of the issue of Shostakovich's putative dissidence. For a strong objection to the applicability of the term, however, see Richard Taruskin, "Public Lies and Unspeakable Truth: Interpreting Shostakovich's Fifth Symphony," in Shostakovich Studies, ed. David Fanning, 17-56 (Cambridge: Cambridge University Press, 1995). For invaluable comments on this essay I am grateful to Richard Turbet.

2 See Anne Barton, "The One and Only," New York Review of Books 53:8 (May 11, 2006): 22-24 and Stephen Greenblatt, The Death of Hamlet," New York Review of Books 51:16. (October 21, 2004): 42-47. Eamon Duffy makes a pointed note of Byrd's Catholicism in this context in "The Plot that Failed," New York Review of Books 53:2 (February 9, 2006): 19-21, at p. 20.

3 Joseph Kerman, "William Byrd and the Catholics," New York Review of Books 26:8 (May 17, 1979): 32-36, idem, "Music and Politics: The Case of William Byrd," Proceedings of the American Philosophical Society 144 (2000): 275-87, Philip Brett, William Byrd and His Contemporaries: Essays and a Monograph, ed. Joseph Kerman and Davitt Moroney (Berkeley: University of California Press, 2006), David Mateer, "William Byrd's Middlesex Recusancy," Music E Letters 78 (1997): 114 and Craig Monson, "Byrd, the Catholics and the Motet: The Hearing Reopened," in Essays on the Motet of the Middle Ages and the Renaissance, ed. Dolores Pesce, 348-74 (New York and Oxford: Oxford University Press, 1997). There is no major polemic on the Catholic issue in Byrd studies, but there are a number of valuable studies that treat non-political or ecumenical aspects of Byrd's religious affiliation. These include John Milsom, "Sacred Songs in the Chamber," in English Choral Practice 1400-1650, edited by John Morehen, 161-199 (Cambridge: Cambridge University Press, 1995), Kerry McCarthy, "Notes as a Garland': the Chronology and Narrative of Byrd's Gradualia," Early Music History 23 (2004): 4984, idem, "Byrd, Augustine, and Tribue Domine," Early Music 32 (2004) and idem, "Byrd's Patrons at Prayer" (forthcoming). I wish to thank Dr. McCarthy for allowing me to consult this essay prior to its publication.

4 On Shostakovich's career in this and subsequent paragraphs see David Fanning and Laurel Fay, "Shostakovich, Dmitry," in Grove Music Online, ed. L. Macy, http://www.grovemusic.com (accessed 23 December 2006). 
deserts by planting a vast forest belt. He held various positions of leadership in the Soviet system and eventually joined the Communist Party in 1963. Yet he also composed bitterly satirical works, such as his Antiformalisticheskii Rayok, attacking Soviet positions on the arts that he found objectionable. Overall, many feel that at the core of his work, where he could bring to bear a highly developed musical language fraught with "colossal emotional power," Shostakovich expressed a consistent and profound disaffection for the Stalinist reign, if not for the Soviet system as a whole.

Byrd enjoyed a position of cultural and economic power in his musical world too, thanks to official ties. 5 Notably, he was a leading member of Elizabeth's prestigious Chapel Royal. Along with his mentor Thomas Tallis, he also held a royal patent for twenty-one years (1575-96) that put him in charge of a monopoly for printed music, printed music paper and music importation. Not surprisingly, Byrd wrote works for the English state and its religion and in these he often evoked Elizabeth herself, as in his "Queenes Alman" for keyboard, his anthem "O Lord, make thy servant Elizabeth our queen," and two madrigalian settings of "This Sweet and Merry Month of May," which celebrated "Eliza" as "the queen of second Troy." No one has detected any irony in these works. Yet there is a larger body of music by Byrd, featuring many settings of sacred texts in Latin, which seems poignantly to betray his ties of allegiance to some of the more militant forces of Catholicism, among them the Jesuit missionary movement that was antithetical to the Elizabethan Settlement.

Finally, and most importantly for our purposes, Byrd and Shostakovich were both to endure dangerous and defining falls from grace. In Shostakovich's case this revolved around a famous incident in 1936, when in the midst of anti-formalist campaigns that merged ominously with deadly purges of Stalin's Great Terror a Stalinist critic writing in the official party newspaper Pravda castigated the composer's opera Lady Macbeth of the Mtsensk District and some of his other work. Commentators have shown that Shostakovich was deeply unsettled in his work for a time after this and that he withdrew his Fourth Symphony from all public venues. The triumph of Shostakovich's Fifth Symphony of 1937, which was awarded a since-persistent subtitle, "a soviet artist's creative response to just criticism," brought to an end Shostakovich's state of troubled insecurity. 6 Now it was generally believed he had found a "new path."

Some regarded the composer's move as a thoughtful, fruitful effort toward compliance with the official agenda for soviet music.7 Others, however, believed that it merely created "two Shostakovichs," and that to find the composer's true feelings one must look for hidden messages that lie beneath the seemingly compliant surface. Whether the Fifth itself ultimately conveys a mood of warmth and "genuine happiness" or the cold resentment of "forced rejoicing" depends on the inclinations of the listener of course. Dmitry and Ludmilla Sollertinsky, in their Pages from the Life of Dmitri Shostakovich, promote the cheerful interpretation while the composer's putative Testimony,

5 On Byrd's life and works see John Harley, William Byrd: Gentleman of the Chapel Royal (Aldershot, Hants: Scolar Press, 1997).

6 On this episode, in addition to New Grove, see Taruskin, "Public lies," 22 and Caroline Brooke, "Soviet Musicians and the Great Terror," Europe-Asia Studies 54 (2002): 397-413. On the subtitle and some apparent mystery surrounding its origins, see Taruskin, "Public lies," 38, n28.

7 See Tim Souster, "Shostakovich at the Crossroads," Tempo, ns 78 (1966): 2-9. 
edited (many would say created) by Solomon Volkov, insists on an underlying bitterness in the music. ${ }^{8}$ It could be argued that Shostakovich's situation made such ambiguity inevitable.

Byrd's fall from grace shares many traits with that of his modern counterpart, but whereas Shostakovich's plight played out in public view, Byrd's troubles resulted from private actions. In the midst of his crisis, however, Byrd apparently also felt compelled to make a public statement of contrition and to demonstrate outwardly his willingness to do his part for the state. Shostakovich's reply took place on the concert stage. Byrd made his presentation in print. Despite his monopolistic power over the music press, Byrd had not used this media as a means of publicizing his or anyone else's musical works for a considerable time since his music had first appeared with Tallis's in an edition of 1575. Thirteen years later, when he did choose to exercise his privilege and return to the press, Byrd did so with a new vigor. ${ }^{9}$ Within three years he published four collections dedicated solely to his own music and he also provided a few works for the two other printed volumes produced in the years 1588 and 1589 under the auspices of his music monopoly. Byrd's volume of Psalmes, Sonets \& songs of sadnes and pietie was the first of these collections to appear before the public and its purpose was apparently to test the ground.10 The result, as I will attempt to show, amounted to something like a Shostakovian "response to just criticism" with all the potential hidden messages and ambiguities that seem now to characterize the modern event.

\section{Byrd and the Throckmorton Plot}

The particular troubles that prompted Byrd's reply are traceable to his association with Lord Thomas Paget and his brother Charles, to whom Byrd taught musical composition.11 In 1580 Byrd was included with these men in a surveillance list of prominent Catholics who were thought to be in close touch with foreign enemies. As John Bossy has shown, government spies were right to be concerned about Byrd's loyalty, as over time the composer deepened his contact with English Catholic exiles in France. ${ }^{2}$ The topics of Byrd's interchanges with his co-religionists were innocent enough, but the surreptitious method of communication was highly suspicious. These letters turned up after Byrd had apparently handled some foreign correspondence for Paget in 1583-84 at a time when Paget was deeply involved in the Throckmorton Plot, one of a long succession of conspiracies designed by Catholics to overturn Elizabeth's Protestant rule.

Some historians-especially modern-day English Jesuits-have claimed that English government officials actually contrived (or nurtured) all such schemes in a clever attempt to entrap and embarrass

8 Dmitry Sollertinsky and Ludmilla Sollertinsky, Pages from the Life of Dmitri Shostakovich, trans. Graham Hobbs and Charles Midgley (London: Robert Hale, 1981); Testimony: The Memoirs of Shostakovich, ed. Solomon Volkov (New York: Harper Row, 1979), 183. The incompatible nature of these two particular views is discussed in Malcolm Barry in his review of Pages from the Life, Music $\mathcal{E}$ Letters 62 (1981): 430-32. On "genuine happiness," see Souster, "Shostakovich at the Crossroads," 6.

9 Jeremy L. Smith, Thomas East and Music Publishing in Renaissance England (New York: Oxford University Press, 2003), 5568.

10 See William Byrd, Psalmes, Sonets and Songs (1588), ed. Jeremy Smith, vol. 13, The Byrd Edition, gen. ed. Philip Brett (London: Stainer \& Bell, 2004), vi (hereafter Psalmes and cited in the text).

11 Harley, William Byrd, 46-50, 58-63.

12 John Bossy, “William Byrd Investigated, 1583-84,” Annual Byrd Newsletter 8 (2002): 5-7. 
their enemies. ${ }^{13}$ But this particular plot, as most concede, was in many respects a serious enterprise. Not only was the Duke of Guise deeply involved but the "king of Spain would bear half the cost."14 Its goal, to free and empower Mary Queen of Scots, was an ambitious one, but it was not unreasonable, especially with all the potential foreign might behind it. Mary was related to the Duke of Guise and her claim to the English throne was strong. The legitimacy of her right to succeed Elizabeth was one reason why she had been held imprisoned in England for some fifteen years by the mid-1580s.

Despite the promising roster of people involved and the rationality of the goal, the Throckmorton plot failed. In the end, it was mainly Englishmen of gentle or lesser rank who took serious measures. Paget was one of the most active of them all and narrowly escaped England with his life when things fell through. ${ }^{15}$ Francis Throckmorton was not as lucky. The unfortunate conspirator was arrested, convicted of treason, gruesomely tortured and then executed for his crime. 16 Further down the list was Byrd, whose involvement had thus far proved to be minimal. Yet he was treated rather firmly. The records show that he was viewed now as one of the "usual suspects" and placed under house arrest. 17 Byrd scholars have known about the incident for some time. What has not been properly credited until recently, however, is how much this may have affected Byrd's career. A prominent co-religionist of Byrd's, the Jesuit William Weston, famously declared that the composer "sacrifice[d] ... everything for [his] faith-his position, the court, and all those aspirations common to men who seek preferment in royal circles as a means of improving their fortunes."18 This has often been seen to misjudge or overstate the case. As David Mateer has astutely pointed out, however, Byrd obviously could not have served at court while under house arrest.19 And Weston was surely right to suggest that Byrd's personal resistance to Protestantism lay at the heart of his political problems.

\section{Music and Elizabethan Politics in the 1570s and 1580s}

In the context of Weston's autobiography where the statement about Byrd appears, it is clear that he wanted to single the composer out. The Jesuit chose few others among Byrd's compatriots to treat so prominently in his accounts. For his religion, Byrd had not only dangerously traversed the line, but he had also established himself as something of a martyr for doing so, a model of how someone of great stature in English life might sacrifice themselves for the Catholic faith. This was a powerful image of Byrd, the man. Where his musical compositions might have fit in with such a nonconformist position, however, is not as easy to discern. As a member of the Chapel Royal, Byrdalong with his fellows in the Chapel and the musicians of the Queenes Musicke-needed to respond to Elizabeth's own politics, which often crossed confessional boundaries. From the start to the end of

13 For a recent, comprehensive treatment along these lines see Francis Edwards, S.J., Plots and Plotters in the Reign of Elizabeth I (Dublin: Four Courts Press 2002).

14 Alison Plowden, "Throckmorton, Francis (1554-1584)," in Oxford Dictionary of National Biography, ed. H. C. G. Matthew and Brian Harrison (Oxford: OUP, 2004), http://www.oxforddnb.com/view/article/27390 (accessed December 23, 2006).

15 Peter Holmes, "Paget, Charles (c.1546-1612)," in Oxford Dictionary of National Biography, online ed., ed. Lawrence Goldman, Oxford: OUP, October 2006, http://www.oxforddnb.com/view/article/21103 (accessed December 23, 2006).

16 Plowden, "Throckmorton, Francis."

17 Bossy, "William Byrd Investigated," 5-6.

18 William Weston, The Autobiography of an Elizabethan, trans. Philip Caraman (London: Longmans, 1955$), 71$.

19 William Byrd, Songs of Sundrie Natures (1589), ed. David Mateer, The Byrd Edition, vol. 12 (London: Stainer \& Bell, 2004), vi-vii. Mateer points out too that it was in this period that Byrd began to be indicted for recusancy (something very likely due to Byrd's enforced absence from the Chapel). 
her long reign, Elizabeth was confronted not only with the vulnerable status of the country's religion, but also the "questionable" capabilities of a woman ruler. ${ }^{20}$ To deal with such issues, she, like most Renaissance rulers, wisely cast her Chapel as something more than a vehicle for personal religious observance. The Chapel's awe-inspiring music for Protestant prayers, for example, could help subdue local critics and the sounds of their Latin motets could send covert messages of various kinds of encouragement to visiting Catholic dignitaries.21 Along with her secular music ensemble, the Chapel could play a role too in royal wooing rituals, where among Elizabeth's potential suitors were a number of Catholics. Eventually, when the time for courtship diplomacy had passed, Elizabeth wisely shifted her royal image to that of the mythological goddess and Virgin Queen.22 Now her musicians found that they too had a new agenda, to evoke pagan rites to celebrate their "immortal," albeit ageing monarch.

From the late 1570 s through the early 1580 s Elizabeth had pursued a highly politicized courtship with François, Duc d'Anjou, a moderate French Catholic. 23 This in fact is where the story of Byrd's Psalmes might be seen to begin. Protestant moderates, who were not much pleased with Anjou's character, his country or his religion, did grudgingly support the match, since they could see benefit in a French alliance that would counter the considerable might of England's cold-war enemy, Hapsburg Spain. On the more radical side of the Protestant wing, however, there were strong objections. This faction looked to the Netherlands, the war's hot spot, where for a short time a rebellion led by William, Prince of Orange was making great strides against Fernando Álvarez de Toledo, the Spanish Duke of Alva. In their view the time was ripe not for compromises but instead for active participation in a glorious religious war.

Meanwhile, Catholic hopes were furthered by the emergence of the Scottish James VI as a king in his own right (1578). Now, with Protestant regents out of the way, it seemed an opportune time for James to reunite with his Catholic mother, Mary Queen of Scots, so that she might take her rightful place beside him as co-ruler of her native country. A busy ambassador for the queen, John Lesley [Leslie], Bishop of Ross, had been campaigning on the continent for foreign support for just such a possibility, and financial backing for his plans seemed to be forthcoming from the Holy Roman Emperor and the Pope.24 On the strength of this movement, some Catholics at the time went so far as to express their fond hopes that James, through his mother's influence and international backing, would soon reconcile with the Catholic faith. Thus as England's queen began the most serious of her royal flirtations among foreign Princes, religious activists on both sides were also making advances in their own respective causes.

20 See Wallace MacCaffrey, Elizabeth I (London: Edward Arnold, 1993), Amanda Shephard, Gender and Authority in Sixteenth-Century England: The Knox Debate (Keele, Staffordshire: Keele University Press, 1994), Louis Adrian Montrose, "'Shaping Fantasies': Figurations of Gender and Power in Elizabethan Culture," Representations 44 (1983): 61-94 and Phillipa Berry, Of Chastity and Power: Elizabethan Literature and the Unmarried Queen (New York : Routledge, 1989).

21 See Craig Monson, "Elizabethan London," in The Renaissance: From the 1470s to the End of the 16th Century. ed. Iain Fenlon, 304-340 (London: Macmillan, 1989).

22 See John N. King, "Queen Elizabeth I: Representations of the Virgin Queen,” Renaissance Quarterly, 43 (1990): $30-74$. King emphasizes the shift in Elizabeth's political agenda after the failed Anjou match.

23 On the Anjou Match and its political aftermath, see MacCaffrey, Elizabeth I, 147-266.

24 D. McN. Lockie, "The Political Career of the Bishop of Ross, 1568-80: The Background to a Contemporary Life of Mary Stuart," University of Birmingham Historical fournal 4 (1953/54): 98-145, at pp. 118-20. 
In the years shortly after 1578, however, Elizabeth kept to her famous via media, while others moved out perilously in opposite directions. Some Protestants spoke out against the Anjou match. In 1579 Sir Philip Sidney, nephew of a most powerful royal favorite and sometime royal suitor, the Earl of Leicester, sent a widely circulated letter to the queen herself to oppose the marriage she favored.25 Sidney was banished or exiled himself from court for this and he retreated for a time to his sister's estate, where he dutifully deactivated politically to reflect on how he might better serve his queen (and compose his famous Arcadia pastorals). 26 On the other side, 1580 was the year that English Catholic exiles Robert Persons and Edmund Campion ventured upon the first Jesuit mission to their native country. This mission was ostensibly pastoral, to serve and instruct a neglected Catholic flock in enemy territory. It was probably, if secretly, also intended to monitor and even foment plans surrounding Anjou and Mary Queen of Scots.27 The eloquent and charismatic Campion was however soon captured by the English government and, after a trial that emerged as a famous debate on religion and loyalty, he was convicted of treason and brutally executed. 28

By the mid-1580s English religious politics were only further polarized. Even before Anjou's death in 1584, England's Catholics had come to view him as too moderate a politique to serve their interests (and he was deeply unpopular in the Netherlands as well). The best Catholic prospects were now James and Mary, who was imprisoned in England. On the Scottish front, the youthful king had recently come under the influence of his Catholic French cousin Esmé Stuart, Sieur d'Aubigny. Shorn of other regents to guide him, James had quickly accepted Aubigny as a close favorite, creating him Earl (1580) and then Duke (1581) of Lennox. ${ }^{29}$ In his meteoric rise to a position of great power Lennox emerged too as a champion of James's mother. He kept in close contact with Mary's powerful Guise relatives in France and this was one of several developments that gave impetus to the Throckmorton Plot that had ensnared Byrd. (Persons was in Paris working with the Guises on this plot soon after the abortive English Jesuit mission.) But the window of opportunity was small. Out of pressure from the Scottish Kirk, and out of love and loyalty to James, Lennox converted to his king's Protestant religion. Ultimately he was forced to move back to France where he died in 1583.

With Anjou and Lennox out of the picture and with the Catholic threat mounting in the Netherlands, especially after the assassination of Orange in 1584, the "hot" Protestants of England finally got their wish. In that year the queen granted them much-demanded support to fight with their co-religionists against the Hapsburgs. It was on this front that Sidney, now finally back in action, was

25 See Irving Ribner, “Machiavelli and Sidney's Discourse to the Queenes Majesty,” Italica 26 (1949): 177-87.

26 See Marion Wynne-Davies, Sidney to Milton, 1580-1660 (London: Palgrave, 2003), p. 20 and Andrew D. Weiner, Sir Philip Sidney and the Poetics of Protestantism: A Study of Contexts (Minneapolis: University of Minneapolis Press, 1979), who take the view that Sidney was banished. Katherine Duncan-Jones disputes the contention in her review of Weiner's book in The Review of English Studies, ns 31 (1980): 451-52 and H. R. Woudhuysen accepts the latter's view in his "Sidney, Sir Philip (1554-1586)," in Oxford Dictionary of National Biography, ed. H. C. G. Matthew and Brian Harrison (Oxford: OUP, 2004); online ed., ed. Lawrence Goldman, May 2005, http://www.oxforddnb.com/view/article/25522 (accessed December 24, 2006). In any case, Sidney clearly left Court under a cloud.

27 See Thomas M. McCoog, S.J., "The English Jesuit Mission and the French Match, 1579-1581," Catholic Historical Review 87 (2001): 185-213 and Michael Carrafiello, Robert Parsons and English Catholicism, 1580-1610 (London: Associated University Presses, 1998), $23 \mathrm{ff}$.

28 Peter Lake and Michael Questier, "Puritans, Papists, and the 'Public Sphere' in Early Modern England: The Edmund Campion Affair in Context," Fournal of Modern History 72 (2000): 587-627.

29 Rosalind K. Marshall, "Stuart, Esmé, first duke of Lennox (c.1542-1583)," in Oxford Dictionary of National Biography, ed. H. C. G. Matthew and Brian Harrison (Oxford: OUP, 2004), http://www.oxforddnb.com/view/article/26702 (accessed December 24, 2006). 
tragically shot in a battle at Zutphen. On 18 October 1586 the brilliant young soldier, poet, courtier and politician died of an infection from the wound he had incurred fighting for the Protestant cause. 30

By the time of Sidney's death Mary Queen of Scots had been implicated in the so-called Babington plot and Parliament had already met to decide her fate. Events from this point onward moved in a curious parallel. ${ }^{31}$ Mary was convicted of treason on 25 October, not long before Sidney's body arrived back in London, on 2 November. Three months later, on 8 February 1587, Mary was executed while Sidney's body remained in internment. It was just two weeks and one day after this, on 25 February 1587, that Sidney was finally buried. The long delay surrounding Sidney's funeral might simply have been due to financial circumstances of Sidney's father-in-law, Sir Francis Walsingham. Apparently Walsingham had had trouble liquidating enough of Sidney's and his own assets to mount an event appropriately solemn and majestic enough for a deceased son-in-law whose fame was fast becoming legendary. ${ }^{2}$ Even at the time, however, many had come to a different conclusion: that Sidney's funeral was so elaborate and scheduled in such close proximity to Mary's so as to distract attention away from the English execution of the dowager Queen of France and Catholic Queen of Scotland. 33

Sidney's memorial was observed on a scale comparable in grandeur (and relative costs) to Princess Diane's of recent times. In contemporary Catholic France, however, it was rivaled by memorial services for Mary, whose death was attracting great attention abroad. Mary was proclaimed a Catholic martyr after many learned of her noble behavior on the day of her execution. ${ }^{34}$ Memorial services at Notre Dame rivaled Sidney's funeral in attendance and attention; and it was through this means of mourning rituals that public opinion itself was pushed to opposite extremes in 1587. It was only, finally, late in the summer of 1588, with the English defeat of the Spanish Armada, that the seeming back and forth of Catholic and Protestant achievements and setbacks went to the clear advantage of one side, that of the English Protestant cause.

\section{A Benigne Reader and a Wicked Foe}

Despite or perhaps because of his Catholic faith and his association with treacherous activities, Byrd went to some lengths to distance himself from political affairs in his Psalmes of 1588. In his preface he addressed a "benigne Reader" and altruistically offered his music up to any of those “disposed to praye ... be merrie ... or to lament [their] sins (Psalmes, xlii)." He did attempt to "perswade every one to learne to sing," presumably to foster book sales (Psalmes, xlii). But this commercial tack could hardly be seen as having much to do with national affairs or religious politics. Questions about English consumers and their musical demands may indeed have been on Byrd's mind after the long period the music press he controlled was inoperative. In his dedication to Sir Christopher Hatton, however, Byrd took yet a further opportunity to explain his (multiplying)

30 Woudhuysen, "Sidney, Sir Philip."

31 Alan Hager, "The Exemplary Mirage: Fabrication of Sir Philip Sidney's Biographical Image and the Sidney Reader," ELH, 48 (1981): 1-16, at p. 6; see also Ronald Strickland, "Pageantry and Poetry as Discourse: The Production of Subjectivity in Sir Philip Sidney's Funeral,” ELH 57 (1990): 19-36.

32 Hager, "Exemplary Mirage," 6.

33 Ibid.

34 On the propaganda surrounding Mary's memorials in France, see Alexander S. Wilkinson, Mary Queen of Scots and French Public Opinion, 1542-1600 (London: Palgrave, 2004), 103-27. 
purposes for publication. Here Byrd absolved himself of underlying political motives. He claimed, first, that the reason he went back to the press was because his friends desired him to do so and because there were faulty copies of his works circulating "abroade." He then cast his "poore songs" as material for "recreation" and "repose," significantly suggesting that Hatton himself might make such use of them after suffering through all his "dayly paines \& cares taken in the high affaires of the Common Wealth (Psalmes, xliv).”

But as much as Byrd's preface spun an apolitical tale, the first work, "O God give ear and do apply," seemed to contradict the story. The text was part of a hallowed Protestant tradition-one of the “compleat psalms" (Ps. 55) John Hopkins had translated famously into common meter. Byrd used it to speak of his "wicked foes," as those who "oppress me through despite (Psalmes, xvi, 3-4)." In the opening musical gesture Byrd shunned the expected Protestant-favored musical style for setting such texts (see example 1). There is no recognizable "church tune" here of the type so often promulgated in Protestant Psalters and this was no simple harmonization. The work opens instead with a defiantly contrapuntal texture suggesting responsorial techniques of liturgical singing, an evocative gesture that conjured up the sounds of outlawed Catholic rites of worship. It was a well-honed technique Byrd may have learned from his mentor Thomas Tallis, who used it to powerful effect in "In ieiunio et fleto," an expressive motet from their joint Cantiones ... sacrae of 1575.35 Opening defiantly, the work ends in paranoid frustration, however, as David complains "they in council do conspire to charge me with some ill ... [and] in their hasty wrath and ire, they do pursue me still (Psalmes, 4-5).”

Joseph Kerman had suggested on stylistic evidence that the first piece to appear in the 1588 set was among the latest works that Byrd had composed prior to publication. ${ }^{36}$ And none of the ten pieces on metrical psalm texts in Byrd's collection-psalms 55, 123, 119 (in two separate sections), 13, 15, 12, 112, 6 and 130-appear in any sources known to have been copied before the Psalmes was produced, although Byrd had set other translations of some of the same sections of these psalms with different music before. Thus stylistic and source evidence converge to suggest that the composer may have conceived these particular works with publication in mind. If so, it is significant that the enemy theme pervades these texts. In "Help Lord, for wasted are those men," from psalm 12, for example, we actually encounter something of the duplicitous Elizabethan espionage agent himself in a "neighbour [that] falshood speakes ... with flattering lips and double heart, when smoothest he doth smile (Psalmes, 29-31)." Others of these psalm settings evoke poignantly the idea of "relief," especially "O Lord, how long wilt thou forget" (ps. 13) and "O Lord, who in thy sacred tent" (ps. 15) (Psalmes, 20-27). This theme of longing and hope was one Byrd also developed conspicuously in motets that have been revealed as thinly veiled political statements for the Catholic cause. As I have noted elsewhere, the contrapuntal style Byrd adopted in these works in particular is akin to these motets and may well have been intended to recall them in spirit (Psalmes, vii). The section ends decidedly nonconfrontationally, however, with excerpts from ps. 6 and 130. These penitential psalms do little to lighten the mood. But they do suggest a conciliatory gesture, one that shows supplication, a willingness to repent and even perhaps a plea (to Hatton), "to give eare unto my plaint ... [and] to help my misery (Psalmes, 41-42)." This was where Byrd chose to mark his first major point of closure. As his printer

35 See Joseph Kerman, “On William Byrd's 'Emendemus in melius,” Musical Quarterly 49 (1962): 431-449, at pp. $446-47$. 36 The Elizabethan Madrigal: A Comparative Study (New York: American Musicological Society, 1962), 112-13. 
faithfully noted in each part-book of the set, "here endeth the Psalms and beginneth the Sonnets and Pastorals (Psalmes, 43).”

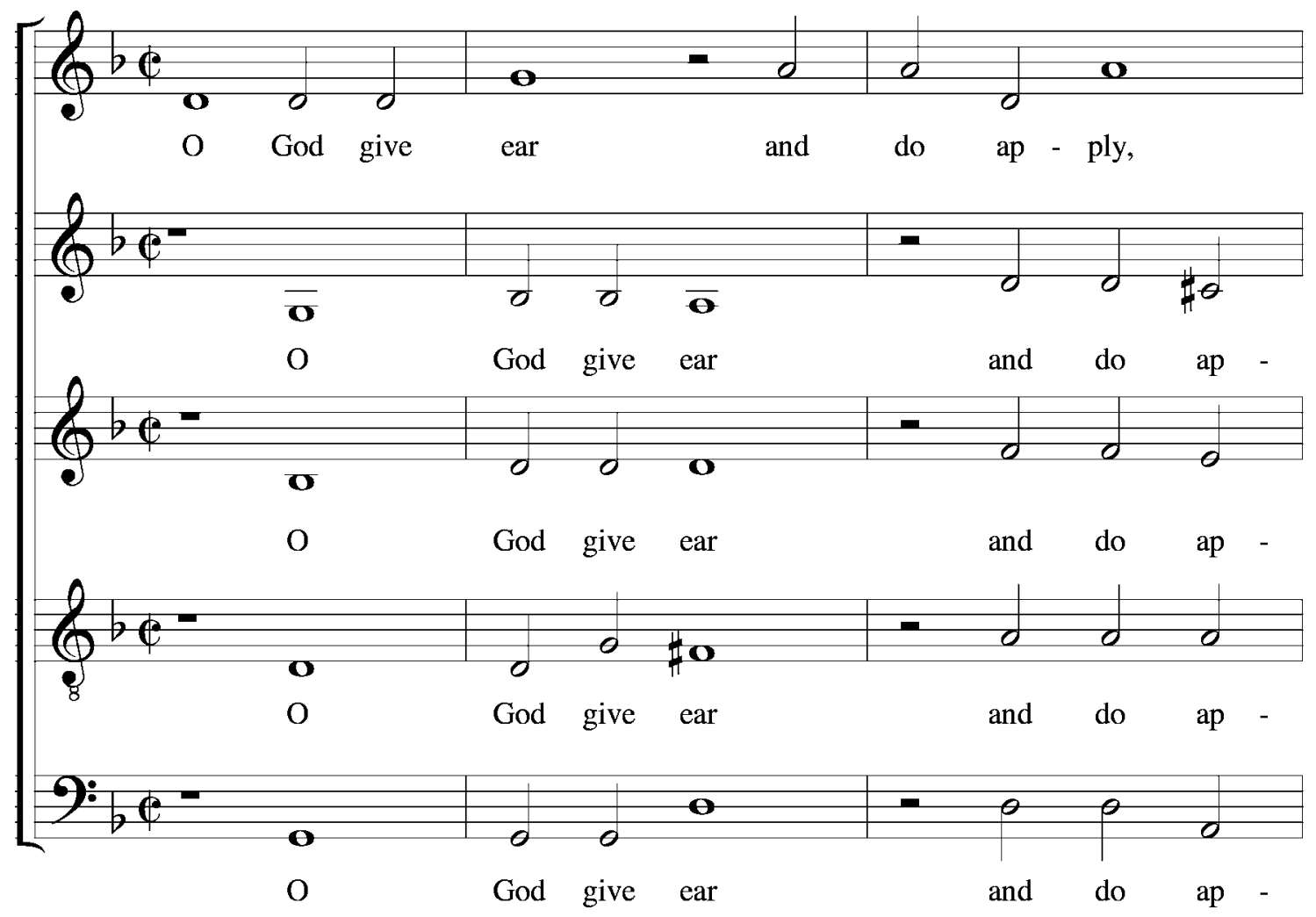

Example 1Byrd, "O God give ear” mm. 1-3

\section{Wealthy Princes and Quiet Minds}

After the somber counterpoint of Byrd's psalms, the songs of this new section-designed as they were for the "merrie" as noted in his preface-offer the listener a bit of tuneful relief. They also contain some pointed messages concerning courtship, marriage and pastoral living. This section opens with Byrd's music for a sententious set of verses entitled "I joy not in no earthly bliss (Psalmes, 43-45)." This was originally part of a long ballad entitled "My mind to me a Kingdom is," of which Byrd also set the opening two stanzas as a separate item, to different music (Psalmes, 55-58). In both portions of the poem worldly riches are spurned. This theme of denunciation was picked up in "Who likes to love let him take heed," where the moral centers around the idea that "golde corrupts the God of love (Psalmes, 54)." A little further along in the set, Byrd set music to two decidedly pastoral verses, which he presented side-by-side in the collection: "What pleasure have great princes" and "As I beheld, I saw a heardman wild" (Psalmes, 73-82). In these latter two works a more particular point is made-that rustic life is preferable to that of the city or court-but the issues surrounding wealth remain prominent. 
Ultimately resonating throughout the set is the idea that "wild heardmen" live better and rest easier than "great princes" and that, as the poem "I joy" concludes, "no wealth is like the quiet mind (Psalmes, 41-42)." How might this topos pertain to anything having to do with religious politics? Bruce Horner helped answer this in his discussion of "What pleasure," when he noted

Gentry who had retired to their country estates untouched by the currents of fashion may have felt the force of this song's appeal strongly, and Catholic gentry, among whom Byrd counted a number of his patrons and with some of whom he probably worshipped, would perhaps feel it most. Country gentry of all religious persuasions may have felt isolated during Byrd's lifetime, but the Catholics actively pursued isolation as a means of privately maintaining their faith. 37

If a certain kind of isolationism was a necessity for practicing Catholics of this era, intriguingly, it was on both sides of the religious debate that parties were pressed into rural confinement, or forced out of politics, so to speak. Catholic conspirators like John Lumley-who was a patron of Byrd's and who had been involved with Mary Queen of Scots in the first years she was in England-had no choice but to withdraw from public life after he had been implicated in treasonous activities surrounding the Ridolphi plot of 1569-72. On the Protestant side, after promulgating his "Discourse of Syr Ph. S.To the Queenes Majesty Touching Hir Mariage with Monsieur" to oppose the Anjou match, Sidney seemed to have been barred from Court in the same manner. 38 Thus there were Catholic experiences in rustic isolation, like Byrd's own, that may well help explain why this particular theme appears so extensively in the set, as Horner suggests. But a more powerful impetus may have come through Sidney, who, it turns out, had developed a particular use of the pastoral context to explore politically pertinent themes of wealth, service and (royal) choice or judgment. Byrd, as we shall see below, had many reasons to focus particular attention on Sidney's career.

Not long before Sidney had written his provocative letter to the queen he had presented her with a masque-fragment entitled "Lady of May." This was performed at an entertainment sponsored in 1578 by the Earl of Leicester during Elizabeth's visit to his Wanstead property. ${ }^{39}$ In this little pastoral drama, the queen was presented with a choice of suitors, namely, a wealthy shepherd, Espilius, and a dutiful, loyal-if still a bit uncontrollable and independent-minded-forester-hunter, Therion. (Intriguingly, Elizabeth's specific task was to judge them on their respective singing abilities.) Both Espilius and Therion of course were "naturally" superior beings as pastoral characters, but Sidney went to some clever lengths to show that this alone was not sufficient cause to value them as consorts, especially in a contest. The wealthy shepherd relied on his hereditary status and wealth; the forester claimed superiority for his ability effectively to serve the right interests. It is not difficult to see that

37 Bruce Horner, “On the Study of Music as Material Social Practice," Fournal of Musicology 16 (1998): 159-99, at p. 195.

38 Leo Gooch notes several periods when Lumley (and his relative Arundel) was put under house-arrest and that after "Norfolk's execution ... the involvement of Arundel and Lumley in politics also came to an end and their intention to devote themselves to art and scholarship allowed Elizabeth to leave them alone," "John, Lord Lumley: An Elizabethan Conspirator and Collector," Northern Catholic History 41 (2000): 10-21, at p. 14. Gooch notes as well that Lumley kept his seat in the House of Lords but never took a prominent role. This describes a pattern: a period of "house-arrest" (selfimposed or otherwise) associated with creative activity and, eventually, something of a changed role in politics. It is striking to see the same pattern in Sidney's poetic/political career, and, indeed, in Byrd's musical/political career, as well. In "Byrd's Patrons," McCarthy treats important aspects of Lumley's religious life after his apparent retreat from politics.

39 Sir Philip Sidney, "Lady of May," e-text edition by Robert Bear, University of Oregon, http://darkwing.uoregon.edu/ rbear/may.html (Accessed 24 December 2006). 
Sidney had set things up so that the forester would win. Yet Elizabeth stubbornly chose the "wrong" suitor (the wealthy shepherd). 40

There is a strong tradition among literary historians to view Sidney's work as a nearly direct representation of the politics surrounding the Leicester party and their opponents at Court. Although this does seem at times to lose sight of the very nature of the play, there can be little question that both Sidney and the queen were using the ludic forum as a means to indicate their positions on political matters. ${ }^{41}$ Indeed it seems that Sidney's message on wealth and service underlined a deepseated view he and others shared about the political factions that had formed around the queen's courtship with Anjou. In his "Discourse ... touching Monsieur," for example, Sidney pointedly (if disingenuously) cast the Catholic faction that supported the match as "men of great number, of great riches, because the affaires of Estate have not lyen upon them." 42

\section{Two Weddings ...}

Other songs among the "Sonnets and Pastorals" deal with love, courtship and marriage. Although he had the advantage of hindsight, Byrd's main objective for this entire section actually seems to have been to recapture the tenor of Courtly politics of the late $1570 \mathrm{~s}$ and early 80s: to place his auditor back into the throes of all the debates surrounding the Anjou match. Some of the songs appear in curious groupings, such as a pair that consists of Byrd's setting of a Sidney sonnet from Astrophel and Stella and some verses by Edward de Vere, Seventeenth Earl of Oxford (Psalmes, 63-72). The arguments of these two poems could hardly be more disparate. Sidney's "O you that hear this voice," as Katherine Duncan-Jones has noted, "takes the form of a legal debate on the priority in excellence between Stella's singing voice and her face." 43 Oxford's "If women could be fair and never fond" bemoaned the changeableness of womankind altogether. The end result was that Sidney built up a

40 Stephen Orgel, "Sidney's Experiment in Pastoral: The Lady of May," Fournal of the Warburg and Courtauld Institutes 26 (1964): 198-203. Edward Berry suggests an interesting reversal in outcomes for Sidney and Elizabeth: that "a year and a half after writing The Lady in May, ironically, Sidney himself retreated from the court and created the exiled courtier Philisides, whose complaints against his cruel mistress entertain the shepherds of the Old Arcadia. By choosing Espilius rather than Therion, one might say, Elizabeth coauthored this persona," "Sidney's May Game for the Queen," Modern Philology 86 (1989): 252-64, at p. 261.

41 On some alternative political readings, such as one that contends that Leicester's own controversial marriage may have been an impetus for the play, see Katherine Duncan-Jones, Sir Philip Sidney: Courtier Poet (New Haven: Yale University Press, 1991), 148-49. Duncan-Jones herself concludes, however, "Sidney's political advice was actually conservative, pleading against violent changes, such as the French marriage," p. 149. Even more pertinently for our argument, in his preface to Sidney, "Lady of May," editor Robert Bear notes that French diplomats may have been present at the performance and suggests that Sidney was voicing "some criticism of [Elizabeth's] tendency to accept the courtship of men who might appear to have much to offer (foreign money and connections), but who could not be expected to have her best interests at heart (due to the same foreign money and connections). At this point the dangerous foreigner was the Duke of Anjou."

42 Quoted in Ribner, "Machiavelli and Sidney's Discourse," 181. Many of the Catholics that Sidney was probably referring to were actually well on the way to debt and other financial troubles, see Gooch, "John, Lord Lumley," 15. Sidney, indeed, may have reconsidered his position on the relative lightness of the burden facing those in the Catholic faction. In 1581 he made an "earnest" (but unsuccessful) attempt to "eas[e] the greatnes" of the recusant Lady Kytson's "burdne" (quoted in Patrick G. Hogan, Jr. "Sidney and Titian: Painting in the 'Arcadia' and the 'Defence," South Central Bulletin 27 (1967): 915, at p. 11). The Kytson family had strong musical connections and it is by no means inconceivable that Byrd (perhaps through his poetic colleague Thomas Watson) knew well about Sidney's act of kindness toward a persecuted Catholic.

43 Katherine Duncan-Jones, “Melancholie Times': Musical Recollections of Sidney by William Byrd and Thomas Watson," in The Well Enchanting Skill: Music, Poetry and Drama in the Culture of the Renaissance, Essays in Honour of F. W. Sternfeld, ed. John Caldwell, Edward Olleson and Susan Wollenberg, 171-80 (Oxford: Clarendon Press, 1990), 173. 
towering conceit to extol his lady's virtues-having them compete among themselves-only to have Oxford knock it all down. Within the confines of the poems themselves, of course, nothing was suggested of this antagonistic relationship. It all had to do with where Byrd placed the poems in his set. But Byrd's decision to effect the juxtaposition was likely not coincidental. Matters that transcended his pages probably inspired him.

During the early stages of the Anjou affair, an enmity between Sidney and Oxford had begun, innocuously enough, on a Whitehall tennis court, when Oxford called Sidney a "puppy" in front of the French ambassador and others of his party. ${ }^{44}$ However minor the infraction might seem today, at the time it took the intervention of the queen herself to prevent matters from escalating into a duel, while nearly verifiable rumors abounded to the effect that Oxford had planned to "to make Sidney awaye" whether in a duel or otherwise. 45 Then, echoing her fictional role in "Lady of May," the queen was asked to make a choice between the two men; and when she did so, Oxford's nobility would trump Sidney's virtues in service. By 1588, when Byrd's set appeared before the public, these events involving Oxford and Sidney had passed into legend. In hearing their poems in close succession like this, though, many may well have recalled the great tensions that had existed between the poets themselves over the issues of service, wealth, religion and the Anjou match.

Byrd created another multiple-poem message with his ordering of the final four pieces of the section, a set that begins with "Constant Penelope" and is followed by "La virginella," "Farewell false love," and "The match that's made (Psalmes, 99-118)." Two of these four poems, the even numbered of the set, concern marriage. La virginella is an ottave rime from Ludovico Ariosto's Orlando furioso that Alfred Einstein aptly described as "composed dozens of times [before Byrd] by Italian and Italianate musicians ... always as festival music for a betrothal." 46 The last work of the set, "The Match That's Made," is clearly of a nuptial kind, if not so much in the burgeoning Elizabethan epithalamic tradition. Unlike Elizabethan poems that imitated the ancient wedding songs, this one contains little in the way of makarismos ("calling happy"), for example, and does not name a date of marriage, fictional or otherwise. 47 But it does contain a message to those who are "married" or "that mind to be"-that Chastity, Concord and, intriguingly, Plenty are the keys to marital success (Psalmes, 118).

However prominent the subject of marriage appears to be in this section, it is colored rather wryly by the presence of "Constant Penelope" at its outset. This poem too had a strong Sidneian connection. It alluded to the real "Stella," i.e., Penelope Devereux, whose betrothal to Robert Rich in 1581 had famously dashed Sidney's hopes and altered his poetic agenda from that time forward.48 Here the verse adds yet another point of tension, unrequited love, to an already strained sequence of poetic texts. Significantly, Byrd had furnished "Constant Penelope" with an artistic conceit of his own: a careful emulation in the main voice of the musique mesuree that Sidney had championed along with others of the so-called Aeropagus group of writers. 49 The musical gesture showed Byrd's deep understanding of Sidney's techniques and poetic preferences and makes it seem altogether unlikely

44 Dwight Peck, "Raleigh, Sidney, Oxford, and the Catholics, 1579," Notes and Queries, ns 23 (1978): 427-31.

45 Quoted in ibid., p. 429.

46 Alfred Einstein, “The Elizabethan Madrigal and 'Musica Transalpina," Music E Letters 25 (1944): 66-77, at p. 67.

47 See Thomas M. Greene, "Spenser and the Epithalamic Convention," Comparative Literature 9 (1957): $215-228$.

48 See Philip Brett and Thurston Dart, "Songs by William Byrd in Manuscripts at Harvard," Harvard Library Bulletin 14 (1960): 343-65, at pp. 52-58.

49 Joseph Kerman, Elizabethan Madrigal, 113 n3. 
that the composer was oblivious to the Sidneian conceit regarding Penelope's marriage or the conflicts that it raised.

Similar tensions were created by the positioning within the set of Sir Walter Ralegh's "Farewell false love," which Byrd placed between the two marriage songs. "Farewell" stands out as an extraordinarily negative attack on Love, which is depicted here as a "sea of sorrows," "poisoned bait," and something that should inspire "trembling fear (Psalmes, 109-113)." Love itself is the target. In the context in which Byrd placed the poem, however, marriage is what seems to stand at the end of this poem's "path that leads to peril and mishap.” A look at Ralegh's sources helps to make this case. As Jonathan Gibson has shown, Ralegh based his poem quite deliberately on "Contr'amour," the work of the French poet Philippe Desportes, who had himself been inspired by an Italian model that Ralegh also knew.50 Gibson concluded that "Farewell"-like both of its models-must have been conceived as the kind of work that invited a poetic answer. Certainly an elaborate "competitive framework" was what Desportes had set up with his verses. As Gibson noted, in the publication in which Desportes's poems appeared, "Contr'amour" is immediately preceded by ... a poem interleaving stanzas which attack Love with stanzas which praise it." 51 At the time he apparently wrote "Farewell," Ralegh, along with Oxford, was a supporter of the royal marriage that Sidney opposed.

It is difficult to judge in the end what Byrd meant for us to glean from this "competitive framework" that he set up in the placement of poems in this last part of his "Sonnets and Pastorals." Was it all to reflect on the falsity of the Rich marriage? Or the failed Anjou courtship? Or any number of others among a long list of controversial Courtly marriages of this era? Or marriage itself? Or all of the above? One hint may appear in Byrd's musical choices. In "The Match That's Made" Byrd put rather astonishing emphasis on the Latin-texted refrain, providing an unexpected shift to a riveting sesquialtera mensuration. Depending on the daring of a given set of performers, this lilting whirl of sound could well approximate the roller coaster ride of today or a frenzied carriage ride then, showing well the potential dangers of a poor match. Or perhaps Byrd went to this trouble just to emphasize the point of the song's refrain "pari iugo dulcis tractus," to outline with great clarity something that Elizabeth herself was quite adamant about when it came to marriage-that the two parties involved should be of equal social standing.52 Even this, however, seems to be somewhat

50 Jonathan Gibson, "French and Italian Sources for Ralegh's 'Farewell false love," Review of English Studies ns 50 (1999): 155-65. Gibson notes that the only four-stanza version is in Byrd's set, and he accepts the theory that Byrd left the fourth stanza out for "musical reasons," p. 162. But the fifth stanza makes a shift, to an autobiographical voice: "sithe then thy traynes my yonger yeares ..." etc. This verse would have ruined Byrd's competitive framework. Thus thanks to Gibson's study it seems better to contend that it was for "poetic" rather than "musical" reasons that Byrd's omitted the fifth stanza.

51 Ibid., 162. Ralegh's "Farewell" was answered too, although not by the poet himself. Outside of Byrd's set, the courtier Thomas Heneage had valiantly defended Love against his fellow poet's attack. A quick glance at their respective titles shows well the connection: Ralegh's "Farewell false love, thou oracle of lyes" was meticulously countered by Heneage's "Most welcome love, thow mortall foe to lies," see ibid., 160-61. Byrd himself may have been aware of the issues that linked the poets of this sequence, although he clearly had other uses for Ralegh's poem. It turns out that Byrd's dedicatee, Hatton and Ralegh were rival royal favorites in the early 1580s and, when they crossed paths, Heneage was the one who had interceded on Hatton's behalf (see Michael Hicks, "Heneage, Sir Thomas (b. in or before 1532, d. 1595)," in Oxford Dictionary of National Biography, ed. H. C. G. Matthew and Brian Harrison (Oxford: OUP, 2004); online ed., ed. Lawrence Goldman, May 2006, http:/www.oxforddnb.com/view/article/12921 (accessed 24 December 2006). But, as Gibson's study of the sources effectively showed, Ralegh's poem was most likely composed no later than 1579 . This helps place the poem, along with Sidney and Oxford's, more securely into the context of factional debates surrounding the Anjou match instead of the Hatton/Ralegh rivalry.

52 Pari iugo dulcis tractus may be translated literally as "the dragging is sweet with an equal yoke," and, more colloquially, "the course is delightful when the pair is well-matched." There well may be an erotic message. I wish to thank my 
contradicted by Byrd's music. Along with coloration and an unusual shift in mensuration, Byrd also juxtaposed notes of decidedly unequal rhythmic values in this section (see example 2). The music Byrd created thus seems to defy the views the maxim was meant to espouse. But it is here nonetheless that Byrd chose to "[end] the Sonnets and Pastorals, and [begin] ... Songs of Sadness and Piety (Psalmes, 119),” with exciting music but with little sense of resolve.
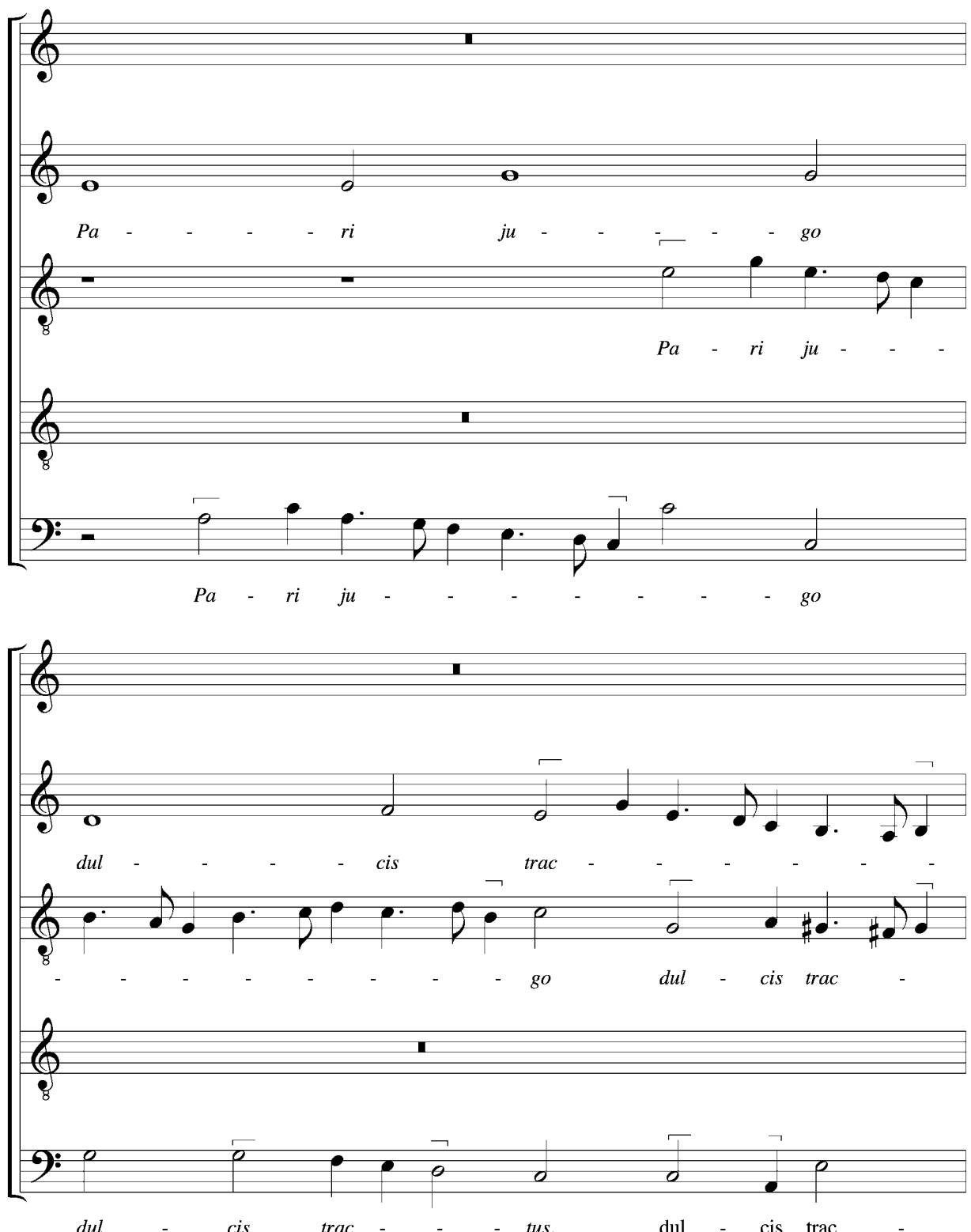

Example 2 Byrd "Match That's Made," mm. 15-16

Colorado colleague in Classics, Professor Alison Orlebeke for this translation. It was likely common enough in Byrd's day, but today it is difficult to find many others who used the phrase. One exception to this is Francis Bacon, who was fond of it. In speeches in the House of Commons he used the maxim to conclude several arguments. Intriguingly, it was once bandied about by Bacon and Ralegh (whose poem stands next to it in Byrd's Psalmes) in a debate over tax policy, see Sir Simonds D'Ewes, The journals of all the Parliaments during the reign of Queen Elizabeth both of the House of Lords and House of Commons ... (London : Printed for John Starkey, 1682), 632-33. On the queen's position regarding equal social status and marriage, see Paul Hammer, "Sex and the Virgin Queen: Aristocratic Concupiscence and the Court of Elizabeth I," Sixteenth Century Fournal 31 (2000): 77-97, especially at p. 81. 


\title{
... and a Funeral
}

The last section of Byrd's Psalmes marks a return to the sober tone of the opening. Here there are poems, like "Prostrate O Lord (Psalmes, 119-22)," and "All as a sea, the world no other is (Psalmes, 123-26)," that recapitulate themes of the former sections, particularly of penance and antiworldliness. Exceptions to this are two songs in the set that depict popular biblical stories: "Susanna and the elders" from the book of Daniel ("Susanna fair," Psalmes, 127-31) and the "Massacre of the Innocents" from the Gospel of Matthew ("Lulla lullabye," Psalmes, 142-49). After "Lullabye" Byrd placed a somber, "Why do I use" (Psalmes, 150-54) and the last two songs, "Come to me grief for ever," and "O that most rare breast" appear after a subheading, "The funeral songs of that honorable Gent. Sir Philip Sidney” (Psalmes, 155-70). As he had in other sections, Byrd took special care with the ordering and placement of the poems in this section. All attention is drawn to Sidney. If, as was suggested above, Sidney's funeral was designed and scheduled to cover-up a controversial execution of Mary Queen of Scots, then Byrd had created a perfect musical analogue to that kind of diversion.

It is important to recognize at the outset that Byrd did not need to label the songs for Sidney as such, at least for the sake of his audience. Anyone who took the time to read through the poems or hear them sung would know immediately what they were about. The mourning tone was unmistakable; and in each of the last two works of the set the deceased poet's name was exclaimed. The second verse of "Come to me grief," for example, ends poignantly "Sidney, O Sidney is dead." Each of the four lines of its fourth stanza began with the word "Sidney." For added emphasis, the printer even italicized every mention of Sidney's name:

\author{
Sidney the hope of land strange, \\ Sidney the flower of England, \\ Sidney the sprite heroic, \\ Sidney is dead, O dead, dead (Psalmes, 157).
}

Byrd seemed to be constrained in his ability to react to this musically, but this, it turns out, was because Byrd was demonstrating again with appropriately long- and short-valued notes his respect for Sidney's experiments with musique mesuree. 53

In the following work, "O that most rare breast," however, Byrd was free to use all of his considerable skills in musical rhetoric to emphasize the poem's subject. And in this he would not disappoint. The main singing part moves into its melody slowly, with a mournful stutter " $\mathrm{O}, \mathrm{O}$ that, $\mathrm{O}$ that most ..." to eventually reach the highest note of the piece with a distinctive new three note motive that Byrd crafted for the text "O Sidney." From there all receded gracefully back to a point of closure for the first part of this ambitiously-scaled work, as the motive echoed through the parts (see example 3). Like many others Byrd seemed determined to show that he would gladly do his part to help with the nation's grieving for a fallen war hero. Even the scale of the work overall reflected the

53 See Derek Attridge, Well-Weighed Syllables, Elizabethan Verse in Classical Meters (Cambridge: Cambridge University Press, 1974), 210. 
extraordinary length of Sidney's funeral; this song takes up some four times the amount of space in the book than any other. 54

There were biblical characters-Susanna, King Herod, King David, etc.-along with some ancient figures and some fictitious shepherds and shepherdesses who were freely named in the book. With the exception of Sidney (and Hatton, the dedicatee), however, Byrd did not refer directly to any contemporary. Even a special reference to Edward Dyer-a particularly close friend of Sidney's-that once appeared in "O That Most Rare" (thy dier here living) was changed in Byrd's setting to a neutral, anonymous text (thy friend here living") (italics mine) (see Psalmes, xxxix). Perhaps this was simply meant to be tactful, but it has left future literary historians somewhat frustrated (or should have left them so), as Byrd seems to have had special access to many important poets and poems and it would have been useful to have had specific citations. Thanks to Byrd's discretion, the first poems by Sidney and Ralegh to appear in any printed edition, for example, were transmitted anonymously. More to the point for our purposes, Byrd omitted the names of poetic subjects such as the Catholic martyr Edmund Campion and, given the set's political context, two other names seem notable in their absence: namely, Mary Queen of Scots and her son James VI.

Byrd's involvement with the Throckmorton plot, limited though it may have been, makes it nearly inconceivable that he was not unaware of, or unaffected by, the execution of Mary. The plot was designed to free Mary from captivity and subsequently to establish her right to rule England or at least to allow her join her newly empowered son as a co-ruler of Scotland. Today we speak (ruefully) of "plausible deniability" and it is possible to hypothecate that Byrd used systems of biblical allusion as a means to build a protective fortress around his dissident actions surrounding these figures, but it is crucial to note that this was also a way he might speak to his "fellow travelers." 55 A closer look at the poems suggests that Byrd did allude to these controversial parties, but this is not as easy to show in some cases as it is in others.

If a veiled allusion to James appears in this section, it would likely have occurred in "Lullabye," Byrd's carol on the biblical story of Herod and the Massacre of the Innocents. Byrd's text closely resembles that of the Coventry Carol that was sung as part of mystery plays at some time in the early sixteenth century. This connection, however distant, is important because it suggests the possibility that Byrd may simply have wished to see through the press a work he had written as part of a musical tradition. Interesting alternative political possibilities for Byrd's choice were not necessarily precluded by this tradition, however. During a royal entry for a three-year-old Edward V that featured music, for example, there was one event where "wine ran in one place, and one of the patriarchs made a speech drawing a parallel between the promise and advent of Christ and the arrival of the prince at Coventry." 56

54 See Strickland, "Pageantry and Poetry," 19-36.

55 Another, more direct, means of communication was through manuscript exchange. This seems to have been a major part of propagandist strategies in disseminating poems about Campion in particular, see Gerard Kilroy, "Paper, Inke and Penne: The Literary Memoria of the Recusant Community,” Downside Review 119 (2001): 95-124.

56 Richard Rastall, “Music for a Royal Entry, 1474,” Musical Times 118:1612 (1977): 463, 465-66, at pp. $463-64$. 
Example 3 Byrd, "O That Most Rare Breast," mm. 1-40
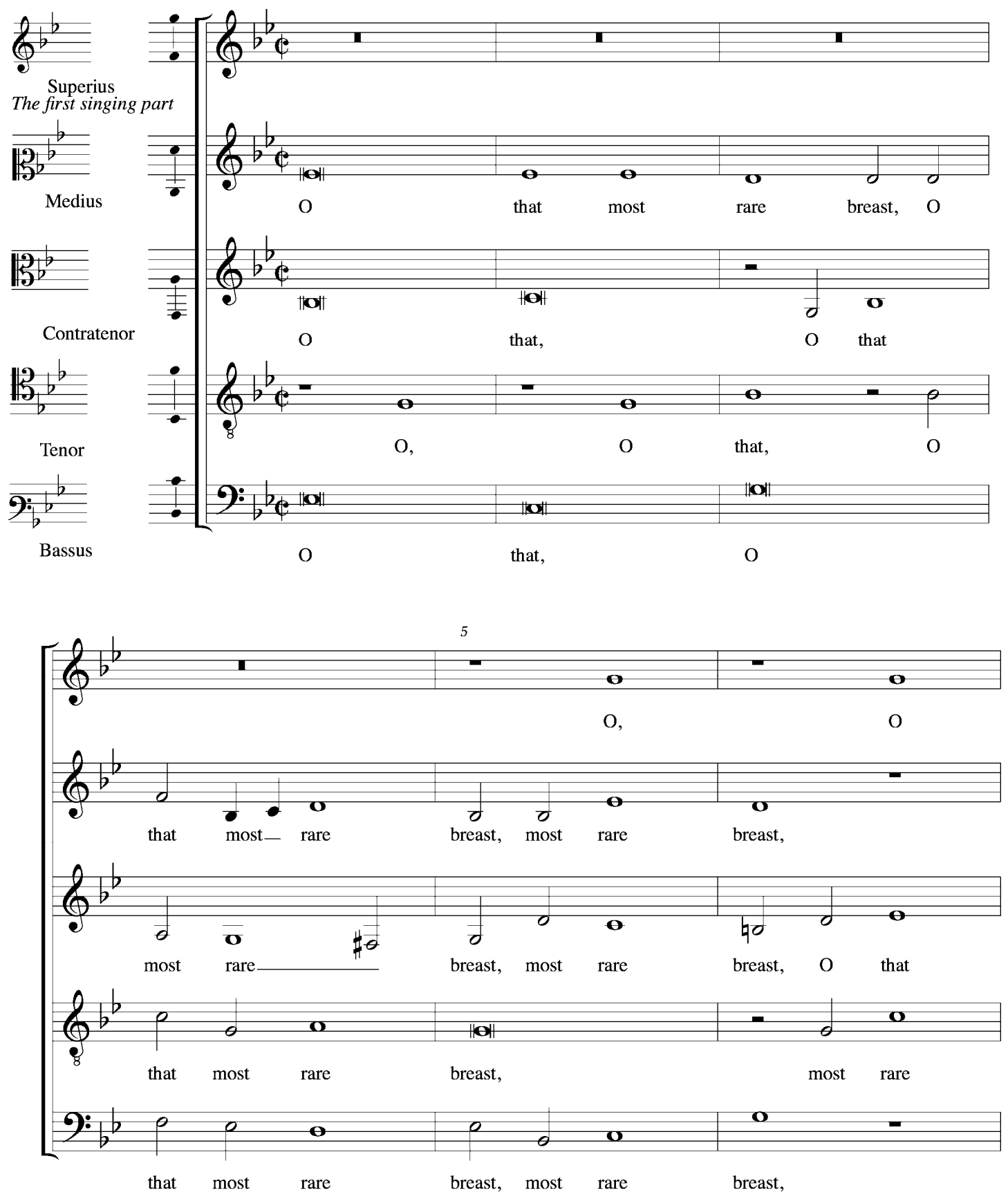
Example 3 continued
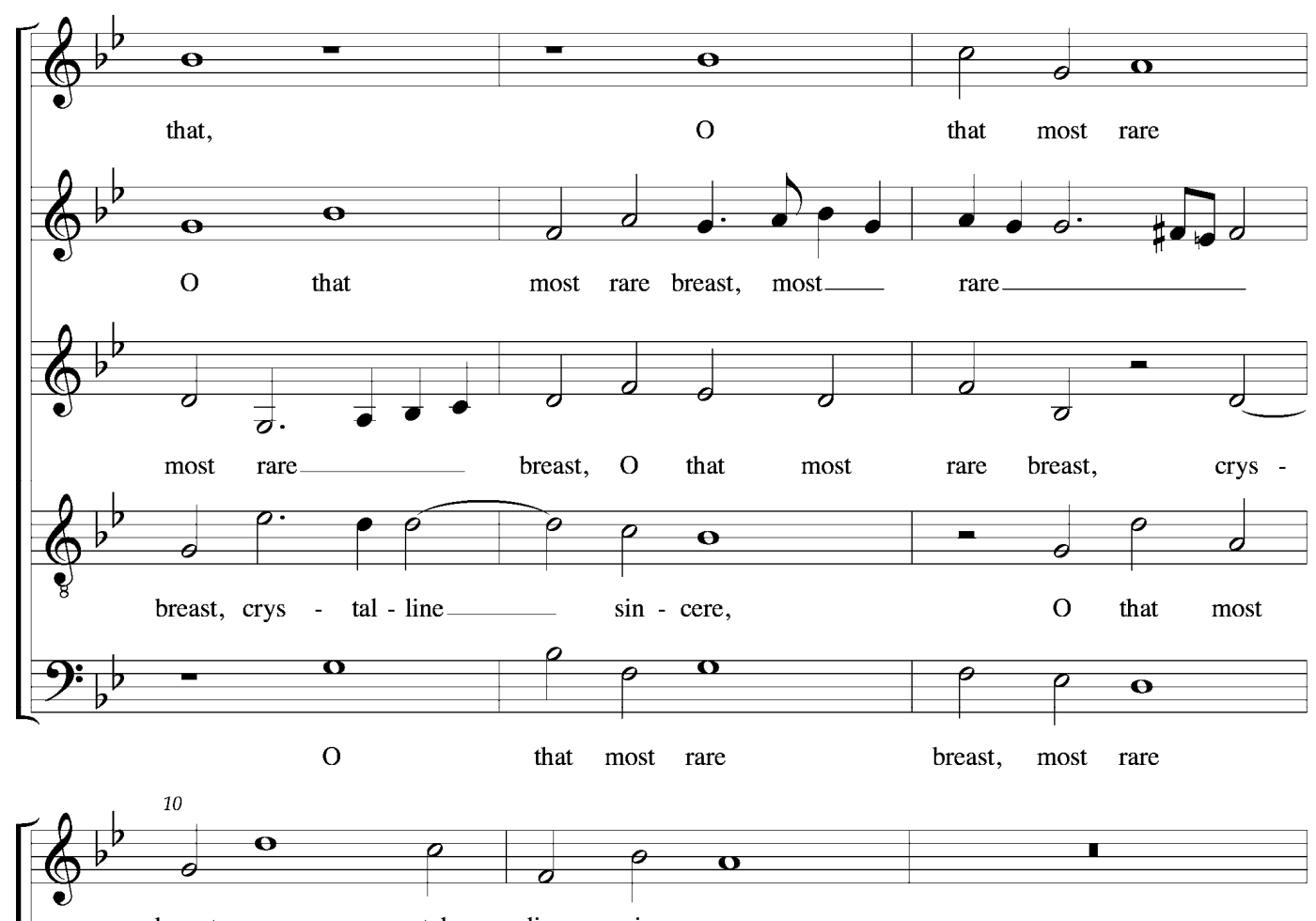

breast, crys - tal - line sin - cere,
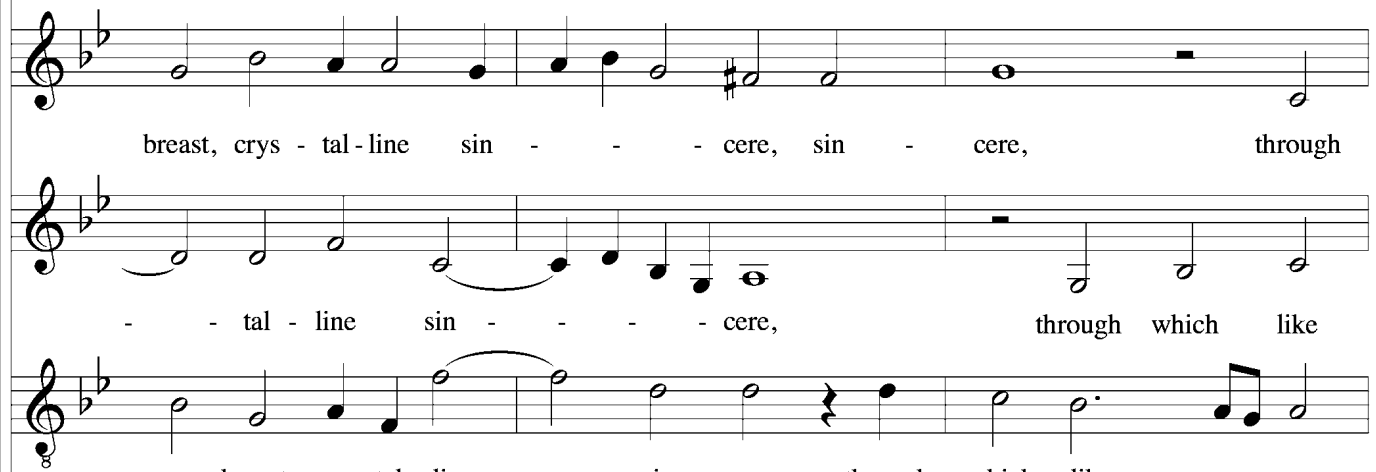

rare breast, crys-tal - line_ sin - cere, through which like

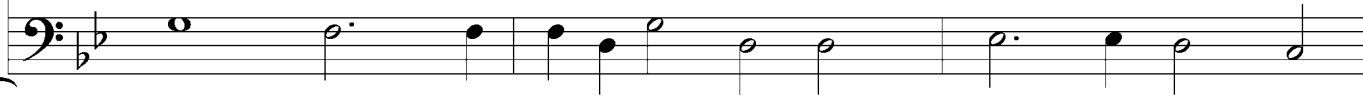

breast, crys - tal - line $\sin$ - cere, through which like gold thy 
Example 3 continued

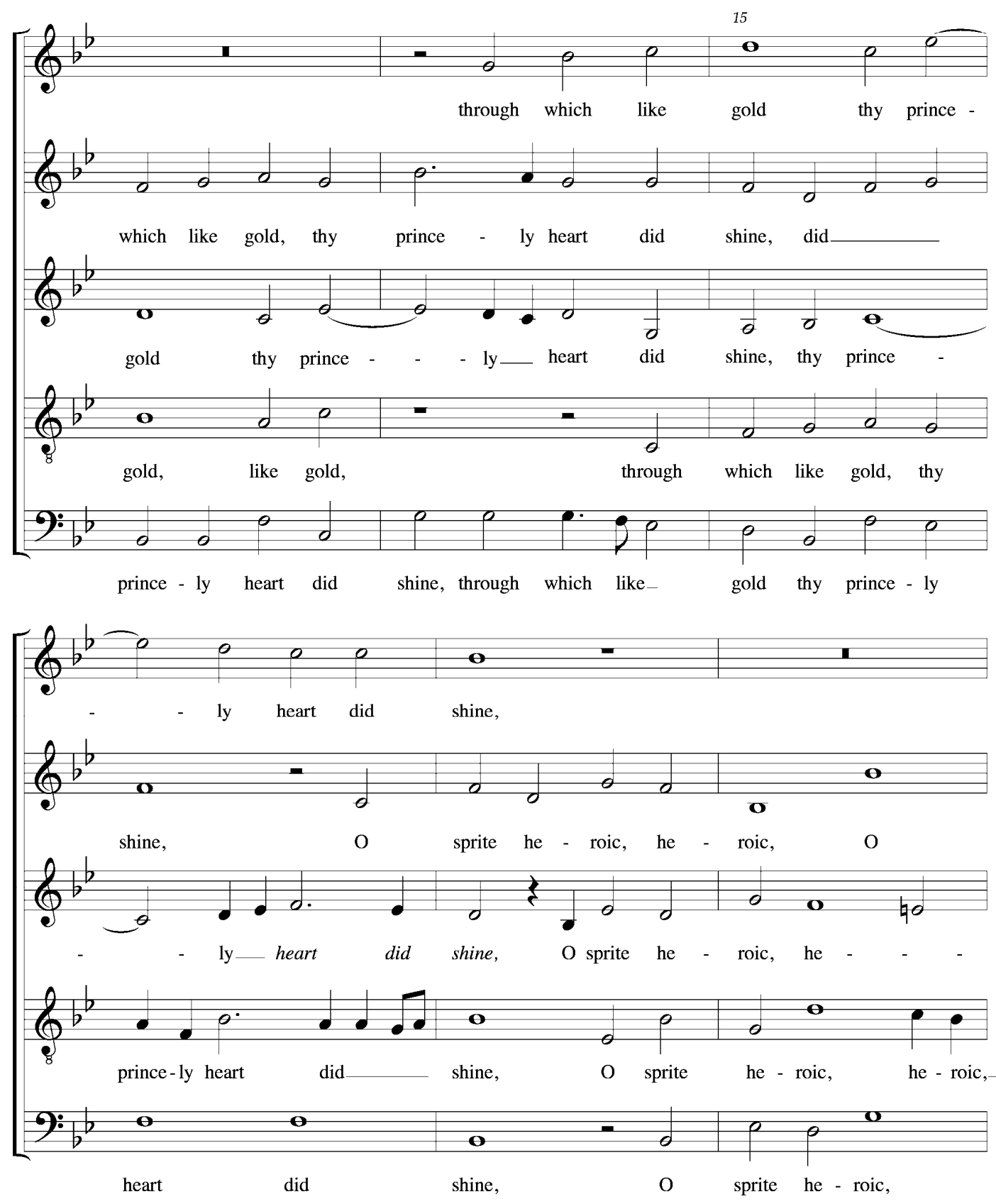


Example 3 continued
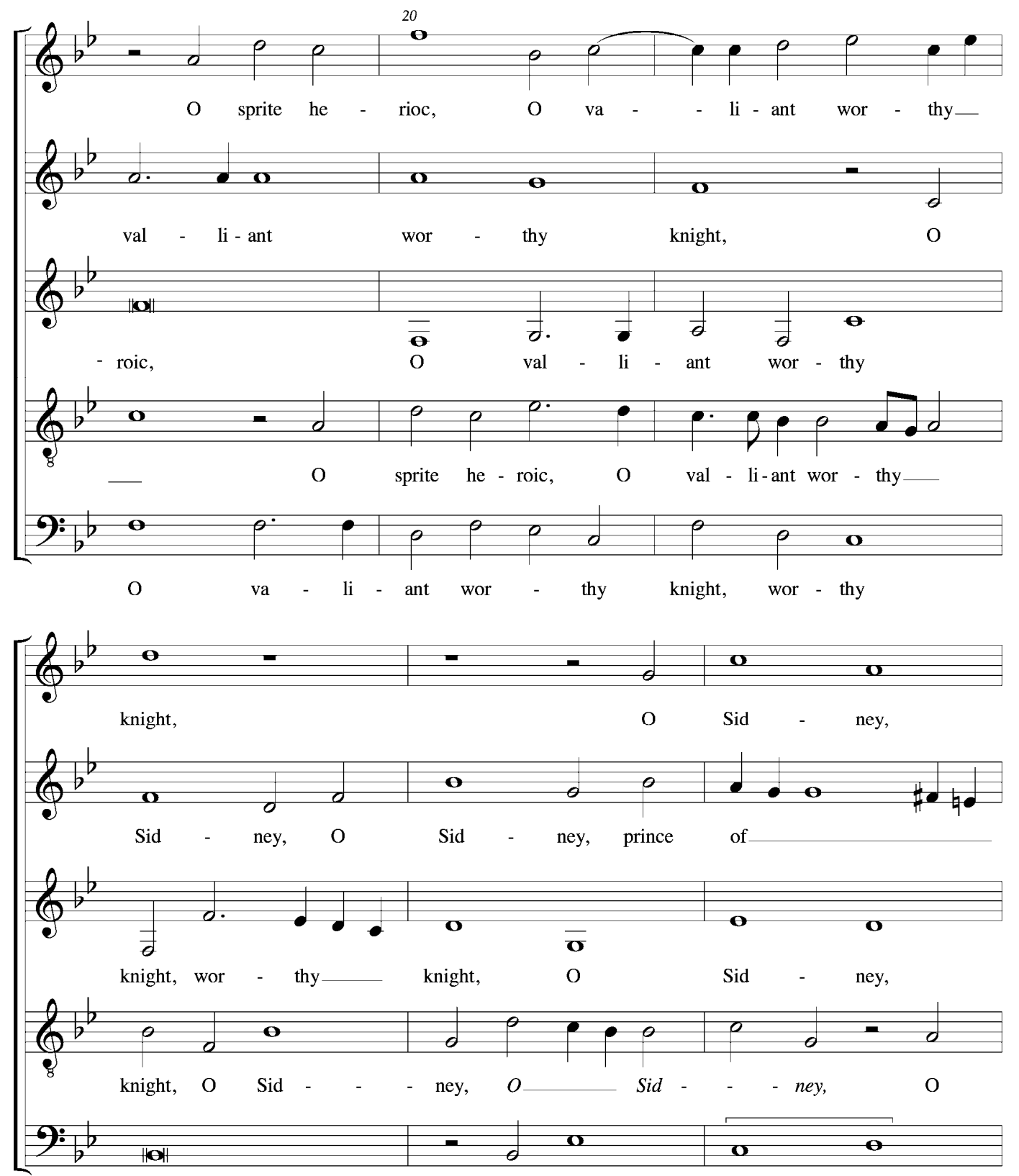

knight,

O Sid - - - ney, 
Example 3 continued

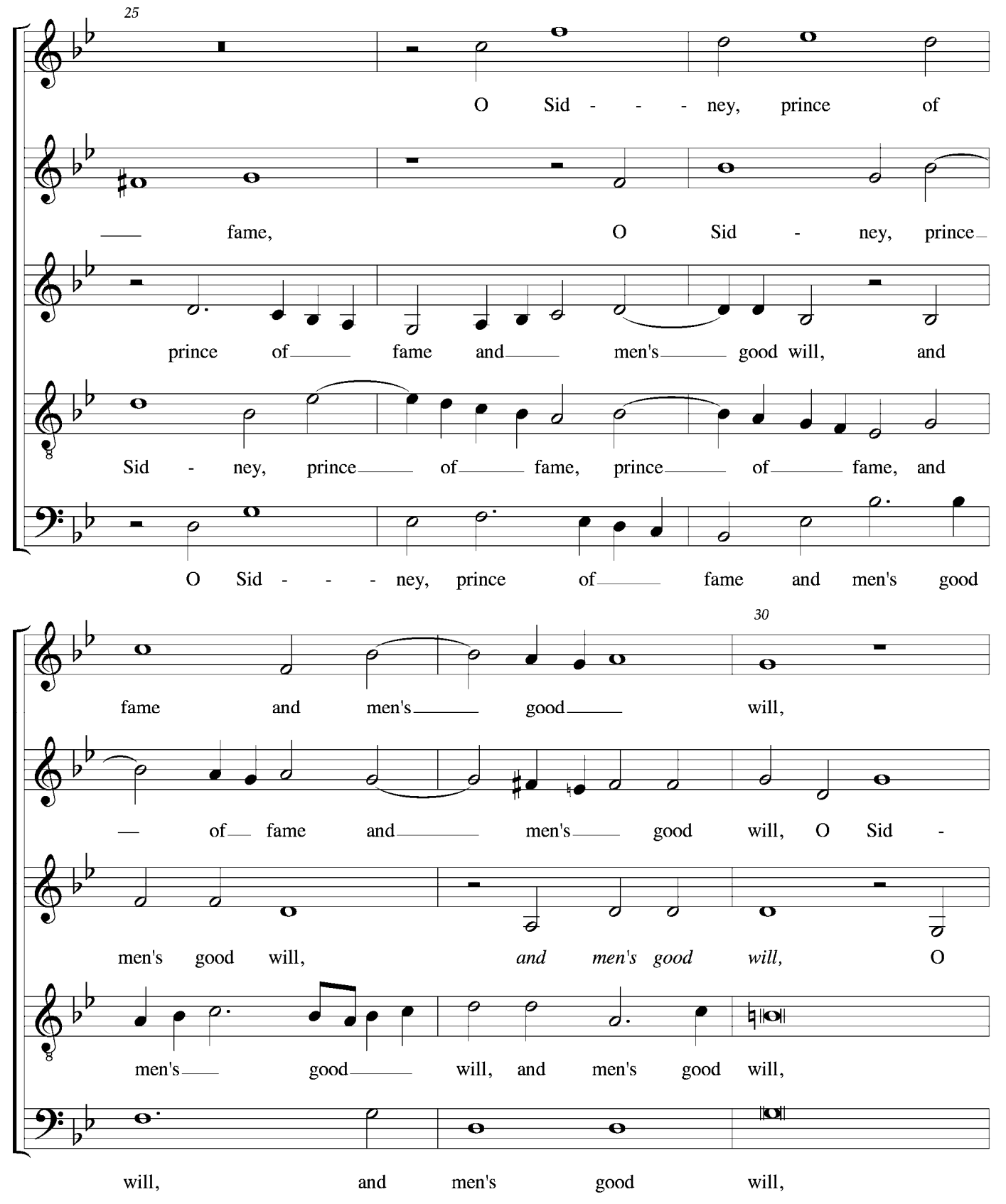


Example 3 continued
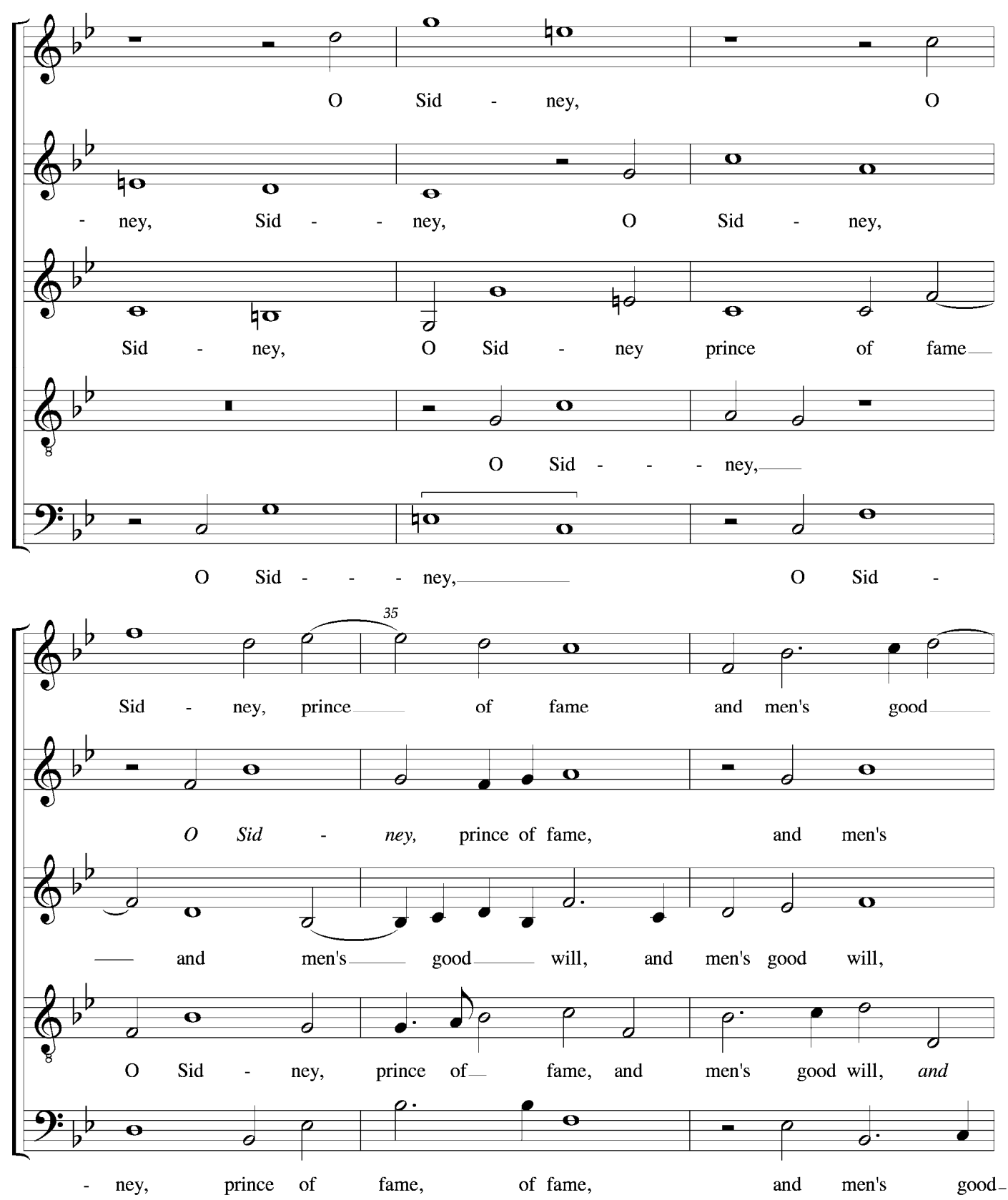


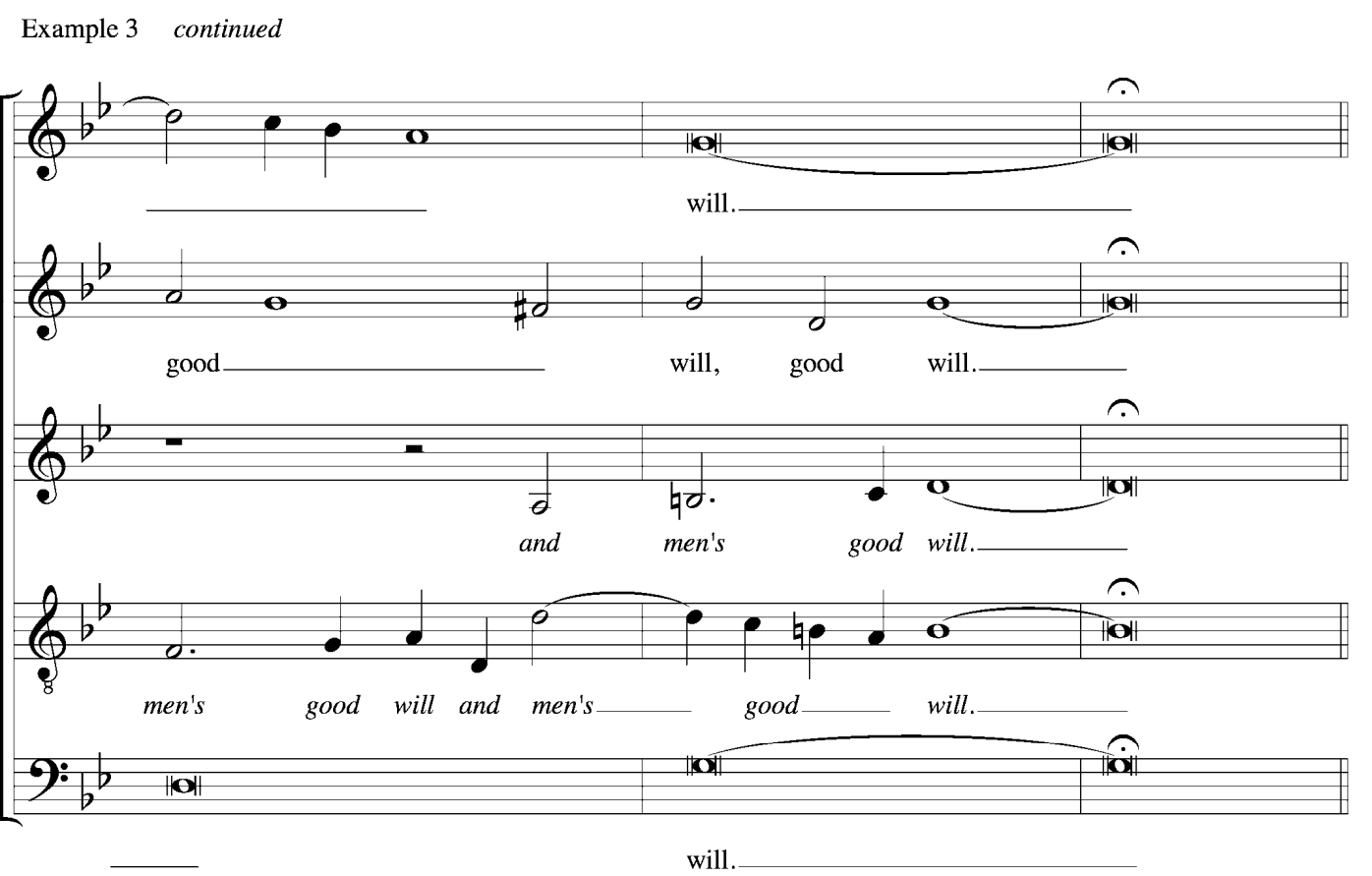

The Herod story itself was also associated with the birth of Christ. Unlike the cheerful association of Jesus and Edward's birth, the more ominous story of a massacre of children fits well with the political circumstances surrounding the birth of James VI in Scotland. As Richard France has noted, the biblical story shared with many tales of folklore an emphasis upon the protective actions of parents as they face the wrath of a tyrannical king's "murderous jealousy of the ruler ... destined to supplant [him]." ${ }_{77}$ Those sympathetic to Mary's plight in 1568 knew that she had left her young son with enemy Protestants in Scotland under the leadership of the hated Earl of Moray (for Catholics a suitable Herod-like figure) as she fled to what she had hoped would be a temporary refuge in England. Tragically, Mary was never to see James again. In 1578, however, when events looked hopeful for a reunion of son and mother, this song may have served to recall for Mary's supporters that earlier period as they looked to a brighter future.

Those among English Catholics who supported Mary herself would also surely have noted how well her life might be compared to that of the biblical character Susanna. In England Mary had been accused of adultery and complicity in a murder. Although an elaborate trial that involved the famous Casket Letters was never quite to materialize, Mary was essentially found guilty of those crimes. 58 And in the end she was tried and convicted of plotting to kill Elizabeth. In both cases, her supporters were adamant in their view that she was wrongly accused. To defend her, several of her staunchest

57 Richard T. France, "Herod and the Children of Bethlehem," Novum Testamentum 21 (1979): 98-120, at. p. 98.

58 It is probably safe to say that of the myriad of works on Mary Queen of Scots, most dwell on issues surrounding her guilt or innocence and her captivity in England (many with and many without the use of supporting evidence). Two of the more recent non-fictional treatments are Retha M. Warnicke, Mary Queen of Scots (London: Routledge, 2006) and John Guy, The True Life of Mary Stuart Queen of Scots (New York: Houghton Mifflin, 2004). I am currently preparing an essay on the Mary Queen of Scots/Susanna question. 
supporters described her situation as akin to Susanna's, whose trumped-up charges of adultery Daniel was able to disprove after collecting separate, conflicting testimonies from the two elders who had together attempted to rape an innocent married woman.59 Thanks to Daniel the elders themselves were convicted and stoned to death. Although Mary was never to enjoy the kind of vindication that Susanna would, her supporters believed that this was her rightful due. Eventually she would die a Catholic heroine, and martyr.

To cast the Catholic Queen as the biblical Susanna was to propagandize for the Marian cause, one with which Byrd could easily be associated. Yet there were plenty of other reasons why Byrd might have composed a work on the Susanna story. In 1548 a relatively obscure composer, Didier Lupi Second, published a setting of Guillaume Gueroult's chanson spirituelle "Susanne un jour," for a decidedly Protestant musical audience. 60 The event would seem rather remote from anything having to do with Byrd. But it would be no exaggeration to suggest that the "Susanna" tradition Lupi started would eventually become the most widespread of any in the entire 16th century. By the time Byrd published his consort song on a related text, there were some three- or four-dozen examples from among which he might have chosen a model, and these ranged from lute arrangements to Mass and Magnificat parodies associated with composers working along a stretch from Portugal to Munich and many areas beyond and in between. 61

Musicological problems abound.62 On the one hand, there is plenty of evidence to suggest that Byrd would have been quite willing to join a tradition like this, and even simply for the sake of the purely musical opportunities it might afford him. Byrd was well known to specialize in the "friendly emulation” of his fellow composers' work. ${ }^{3}$ On the other hand, if Mary was the inspiration for a Byrd Susanna, perhaps she may have been the inspiration for others in the series as well. There would be plenty of works to sort through to check for this possibility. Kenneth Levy has noted that Protestants would naturally have been attracted to the text. But he also showed that many Catholic composers set it as well and to explain this he intriguingly surmised that they "made a special point of pillaging the Huguenots' musical arsenal by appropriating Susanne as a symbol of their own." 64 Clearly a proper

59 E.g., John Leslie, A defence of the honour of the right highe, mightye and noble Princesse Marie Quene of Scotlande and dowager of France ... (London [i.e. Rheims]: Eusebius Dicæophile [i.e. J. Foigny], 1569), "We can tell you that this good ladie ys uniustlie accused and wrongfullie oppressed, as good Sussana was," pp. 44-45.

60 See the classic article by Kenneth Jay Levy, "Susanne un jour': The History of a 16th Century Chanson,” Annales Musicologiques 1 (1953): 376-408. Although extensive, the list of works in this study is by no means exhaustive.

61 The Portugese composer Manuel Rodrigues Coelho wrote four intabulations of "Susanas grosadas" for organ, see Howard Brown, Review of Manuel Rodrigues Coelho: Flores de musica pera o instrumento de tecla E harpa. Vol. II: Composiçoes sobre temas litúrgicos, by Macario Santiago Kastner, Notes 20 (1962/63): 117-118. Of all composers associated with the series, Orlande de Lassus was the most influential. David Crook notes "Lasso's own five-voice chanson was probably the most celebrated. The complex of 'Susanne' compositions within Lasso's own corpus is also unparalleled. Nowhere else do we find a group of related pieces that spans so many genres-in addition to the chanson (1560), a German Lied (1576), a Mass (1577), the Magnificat (before 1581), and possibly a Nunc dimittis setting (c.1570)," Orlando di Lasso's Imitation Magnificats for Counter-Reformation Munich (Princeton: Princeton University Press, 1994), 177.

62 One is cheered nonetheless by John Purser's view that an “intelligent listener ... aware of the story itself ... would have have had to have been pretty thick-skulled not to be drawn into associating with relevant contemporary views: and it is equally sure that this music is pleading Susanna's innocence with a beauty and dignity which must have brought Mary Queen of Scots to mind, "On the Trail of the Spies," Scotlands 5 (1998): 23-44, at p. 33. As far as I know Purser has not pursued this any further. With much less to go on, I had independently come to the same basic conclusion last year, see "A Newly Discovered Edition of William Byrd's Psalmes, Sonets E Songs: Provenance and Significance," Notes 62 (2005): 273-298 at p. 295.

63 Susan Hankey, “The Compleat Gentleman's Music,” Music E Letters 62 (1981): 146-154.

64 Levy, "Susanne un jour," 380. 
study of this "Susanna question" would require considerably more space than this study can bear. For the sake of the present argument, however, perhaps it need only be noted that Byrd could well have had more than one reason to compose and publish such a work. It is also likely that the English men and women who would encounter this piece in Byrd's Psalmes were probably more familiar with the situation regarding Mary than with the musical tradition.

Unlike the uncertainty associated with the Mary/Susanna allusion, there can really be no question that in his setting of "Why do I use" Byrd was referring obliquely to a figure of great prominence in the Catholic world. This poem was one of the most famous works composed to commemorate the martyred Jesuit Edmund Campion who had been executed in 1581. Henry Walpole, the probable author, had witnessed Campion's execution. Soon thereafter he converted to the Catholic faith and joined the Jesuit fold, only to suffer martyrdom himself in 1595.65 In a stanza Byrd (wisely) chose not to publish the tone is similar to that conveyed by the psalms opening his 1588 collection, namely, a tauntingly threatening address to a hated enemy:

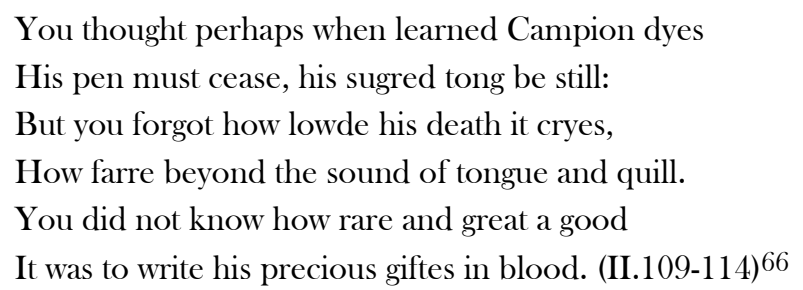

Before Byrd had published a stanza of this verse, Stephen Vallenger had been severely punished for his attempt to bring it to public view. 67 One suspects that Byrd courted similar dangers by reintroducing to print any part of the poem. But Byrd would set back into print a nearly exact version of the first stanza of the poem, one that alluded to Campion's "tongue and quill" and one that overtly extolled the power of martyrdom. The composer made no attempt to remove any trappings of Catholicism in his rendition. References to "martirs" and "saints" leave no question on this account:

Why do I vse my paper incke \& pen, and call my wits to counsel what to saie, such memories were made for mortall men, I speak of Saints, whose names cannot decaye, an Angels trump, were fitter for to sound, their glorious death, if such on earth were found.

That stoare of such were once on earth pursu'd, the histories of auncient times record, whose constancie great tirants rage subdu'd, through patient death professsing Christ their Lord, as his Apostles perfect witnesse beare, with many more that blessed Martirs were.

65 See Kilroy, "Paper, Inke and Penne," 96.

66 The Arundel-Harington Manuscript of Tudor Poetry, ed. Ruth Hughey, 2 vols. (Columbus: University of Ohio Press,), 2:66. See also Phebe Jensen, "Ballads and Brags: Free Speech and Recusant Culture in Elizabethan England," Criticism 40 (1998): 333-54.

67 Kilroy, "Paper, Inke and Penne," 95. Kilroy curiously ignored Byrd's edition when he stated "this text disappears from view [in print] until used as a basis for the 1908 edition of the poem." 


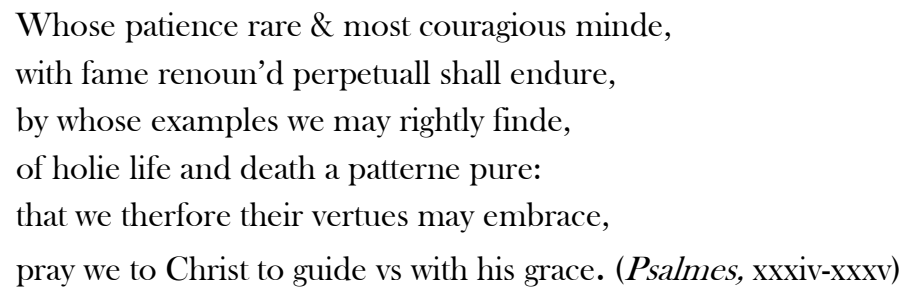

Was this Byrd's means of achieving a Catholic inversion of the Protestant agenda? Certainly those who knew well the actual Walpole poem from which Byrd's stanzas derived may have come to such a conclusion. There were Catholics who, following Weston's lead, proudly saw Byrd's efforts as part of their cause. One of them recalled Byrd's setting of these verses, noting that they had been "set forth in music by the best musician in England (Psalmes, xxxix)." Clearly this was the view of a Catholic "fellow traveler," someone who saw through all the Protestant-sanctioned veneration of Sidney into the "real" purposes of Byrd's music. Yet any Protestant who knew the whole story might still have been quite satisfied. What better way to contain the threat of Catholic insurgence than to show through the magnificent and imposing display connected with Sidney's funeral how it would be overwhelmed by the power of a righteous Protestant cause? And so on.

Given Campion's fame and the fact that the poem Byrd reproduced in part had been published before, it may be fair to ask, in the end, if Byrd's allusion to the great Jesuit martyr was ever really "hidden" in any real sense of the word. Catholics would have expected Byrd to make his points to them in veiled terms. Perhaps-as he seemed to be doing with his redundant headers in the face of abundant textual and musical emphasis on the name "Sidney"-Byrd's point was to make a clear show of his best intentions; and if Protestants expected a blatant act of loyalty, this was something with which Byrd would also comply. If this was Byrd's "creative response” it was an extraordinary one, for it served both sides.

Yet there is a viable alternative even to this theory. Katherine Duncan-Jones has pointed out that Campion and Sidney had met once in a diplomatic setting in Prague. Away from the heated arguments of their homeland, the two men were free to discuss matters openly, and Duncan-Jones conveys well the sense that a mutual admiration was the result of their meeting, despite their religious differences.68 I suspect Byrd knew about this unusual meeting and its implications. If so, the intersection in the lives of these two figures was probably not lost to him as he drew them together posthumously in his book. Indeed, after the "competitive framework" Byrd established on marriage, it is striking to note just how thematically complementary the last three elegiac poems appear to be once they are viewed outside of the context of such a divisive world of religious politics.

Some may have had the composure to contemplate this unusual moment of unity among such great figures. But it seems unlikely that many others at the time would have focused on this poignant momentary bridging of confessional hostilities. Most surely were operating with a sense of urgency. Byrd's funereal songs probably reminded them of the bloody results of religious strife confronting their coreligionists throughout Europe. If there is some value in drawing this analogy between Byrd

68 Sidney: Courtier Poet, 124-27. 
and Shostakovich it may be in reminding us of this, in forcing the historian back to the hard choices Byrd faced and the general harshness that marked this aspect of the Elizabethan era.

\section{The Ethical Responsibility of Artists}

Was there a similar reaction to Shostakovich's Fifth Symphony? We wrestle still with a myriad of complex political and musical polemics and debates about Shostakovich that frustrate the chance to sort this out. On purely emotional terms, however, the most immediate response to the Fifth was apparently strong and clear: It was, as Malcom Brown described it, "tumultuous. Both men and women wept openly during the Largo, and as the finale reached its culmination people started to rise involuntarily from their seats, transfixed by the intensity of their emotional response to the music." 69 This could not have been due merely to Stalinistic approval, or even to some expression of the "mass indoctrination that included the hardening of the Stalin personality cult."70 Richard Taruskin suggests that the visceral response is explained by the audience's immediate appreciation of coded messages Shostakovich had embedded within his music. Specifically, that through a Beethovian and Mahlerian method of sending messages through musical gestures, Shostakovich had hidden within the work (in the Largo) a "mourning piece," a hidden funeral march for the victims of Stalin's Great Terror, one that had meaning, sadly, for "every member of the symphony's early audiences" who "had lost friends and family members during the black year 1937, loved ones whose deaths they had had to endure in numb horror."71 Other scholars may have different views, but there are surely few today who would cast Shostakovich very far into the Cult of Stalin.

Once seen as a purely entrancing force, the phenomenon known as the Cult of Elizabeth is now more often viewed as a political mechanism, a method of domination and containment or a means of mediating and defining royal power. ${ }^{2}$ Something of all these aspects of the force of the Elizabethan cult probably affected Byrd in his work on the Psalmes. Indeed, if there is anything of an apology to be found in this work it was one to his queen (the dedicatee Hatton, a royal favorite, was the perfect conduit for this kind of a gesture). But as Byrd apologized to Elizabeth he was also trying to teach her something. And as he formulated the points he wished to make to his sovereign, rather many other personalities seemed to have floated through Byrd's mind, including Sidney, Campion, Mary Queen of Scots, Lumley, Ralegh, Anjou, Walsingham, Hatton, James VI, Oxford, Orange, Lennox, Persons, Paget, and surely many others. They loomed large in Byrd's world and, in some cases, the way their legacy was cast was especially important to him.

On the matter of royal marriage Byrd seemed willing to leave all these people aside and show a decided preference for the views of his queen; he seemed indeed most anxious to show that marriage was a dangerous business and should be treated with utmost care. Respectful of Elizabeth's unwillingness to make hasty decisions, he prevaricated too. But on the deaths of Campion, Sidney

69 Review of Defining Russia Musically: Historical and Hermeneutic Essays, by Richard Taruskin, Notes 55 (1998): 71-74, at p. 74.

70 Taruskin, "Public Lies," 19.

71 Ibid., 42.

72 See Jeremy L. Smith, "Music and the Cult of Elizabeth: The Politics of Panegyric and Sound," in Noyses, Sounds and Sweet Airs: Music in Early Modern England," compiled and edited by Jessie Ann Owens, 62-77 (Washington DC: The Folger Shakespeare Library). 
and even Mary Queen of Scots, Byrd may have been acting as the "holy fool" (yurodivy): someone who was expected to speak freely and who was not afraid to counter the views of his or her ruler. However one interprets Byrd's intentions in his juxtaposition of songs for martyrs, he showed well that there were great and widely admired figures dying on all sides while Elizabeth was busy listening to those on the left of England's spectrum of religious politics. Byrd wrote "songs of sadness and piety" for a nation that was very much in need of "mourning songs" and he seems to have had the courage to present a moderate, if not a reactionary, viewpoint concerning the whole issue as he presented his "response" to his queen.

Ultimately then state funerals stand at the heart of these two "responses to just criticism." If one had to be blatantly announced and the other had to be "hidden," this may well reflect the divergent times and the divergent issues that these two composers faced. It does not seem to change the humanity that both musicians seemed most capable of and interested in expressing as responsible members of their respective states. Was Byrd's Psalmes a "response to just criticism?" I would very much like to think that Byrd, like Shostakovich, performed well at a time when he was put to a severe test, when issues like the "moral ambiguity of idealism [and] the inescapable ethical responsibilities of artists" were at stake not only for him, but also for many around him.73 Others may obviously take a different view, and it would belittle Byrd's art to imagine otherwise. But, in any case, my answer to the title question, "Was Byrd's Psalmes a response to just criticism?" is ... yes, every bit as much as was Shostakovich's Fifth Symphony.

73 Taruskin, "Public Lies," 56. 